\title{
Preparation of Large Conjugated Polybenzimidazole Fluorescent Materials and Their Application in Metal Ion Detection
}

\author{
Xi-Ying Cao ${ }^{1}$, Chu-Ming Pang ${ }^{1,2, *}$, Ying Xiao ${ }^{1}$, Wan-Qing Xiao ${ }^{1}$, Shi-He Luo ${ }^{1} * \mathbb{D}$, Jin-Ping He ${ }^{1}$ \\ and Zhao-Yang Wang ${ }^{1, *(\mathbb{D})}$
}

check for

updates

Citation: Cao, X.-Y.; Pang, C.-M.; Xiao, Y.; Xiao, W.-Q.; Luo, S.-H.; He, J.-P.; Wang, Z.-Y. Preparation of Large Conjugated Polybenzimidazole Fluorescent Materials and Their Application in Metal Ion Detection. Polymers 2021, 13, 3091. https:// doi.org/10.3390/polym13183091

Academic Editors: Thanh-Hai Le, Mincheol Chang and Dang Viet Quang

Received: 18 August 2021

Accepted: 10 September 2021

Published: 14 September 2021

Publisher's Note: MDPI stays neutral with regard to jurisdictional claims in published maps and institutional affiliations.

Copyright: (c) 2021 by the authors. Licensee MDPI, Basel, Switzerland. This article is an open access article distributed under the terms and conditions of the Creative Commons Attribution (CC BY) license (https:/ / creativecommons.org/licenses/by/ $4.0 /)$.
1 School of Chemistry, South China Normal University, Key Laboratory of Theoretical Chemistry of Environment, Ministry of Education; Guangzhou Key Laboratory of Analytical Chemistry for Biomedicine, Guangzhou 510006, China; 2019022188@m.scnu.edu.cn (X.-Y.C.); 2019022193@m.scnu.edu.cn (Y.X.); 2020022598@m.scnu.edu.cn (W.-Q.X.); 20172421078@m.scnu.edu.cn (J.-P.H.)

2 School of Health Medicine, Guangzhou Huashang College, Guangzhou 511300, China

* Correspondence: 2017021874@m.scnu.edu.cn (C.-M.P.); luoshihescnu@m.scnu.edu.cn (S.-H.L.); 19951088@m.scnu.edu.cn (Z.-Y.W)

\begin{abstract}
A new type of conjugated polybenzimidazole (CPBI) was synthesized through a simple polycondensation reaction without metal catalysis, and $\mathrm{N}$-alkylation modification was carried out to solve the problems of solubility and fluorescence properties. A series of nano-microsphere polymers $\mathrm{CPBI}_{n}$ with large conjugation, good solubility, and strong fluorescence has been successfully used as "turn-off" fluorescent probes for the first time. The results show that, under suitable $N$-alkylation conditions, the obtained $\mathbf{C P B I}_{n}$ can be used as a highly sensitive and selective fluorescent probe for the detection of $\mathrm{Cu}^{2+}$ and $\mathrm{Zn}^{2+}$ at the same time, and their detection limits are both $\mathrm{nM}$ levels. In addition, $\mathbf{C P B I}_{2}$ can be designed as an ultra-sensitive IMPLICATION logic gate at the molecular level, cyclically detecting $\mathrm{Cu}^{2+}$. With the test paper containing $\mathbf{C} \mathbf{P B I}_{2}$, easy and quick on-site detection can be achieved. This research provides a new idea for the brief synthesis of multifunctional materials.
\end{abstract}

Keywords: large conjugation; polybenzimidazole; fluorescent probe; $N$-alkylation modification

\section{Introduction}

Conjugated polymer molecules are important materials for optoelectronic applications because they provide a relatively direct link between optoelectronic properties and compound structures [1]. Compared with non-backbone conjugated polymeric probes, organic backbone conjugated polymers are composed of unsaturated structural units, such as aromatic hydrocarbons, olefins, or acetylene, making the formation of a large delocalized polarizable $\pi$-electronic domain easy [2]. For their excellent optical and electrical properties, more and more attention has been paid to them [3]. At the same time, their molecular chains may function as "molecular lines", along which energy and electric charges can move. This unique performance determines the ability to detect ultra-low concentrations of analytes [4-6]. Therefore, the synthesis and application of organic conjugated macromolecular chemical sensors have attracted more and more attention [7-9].

Copper ion and zinc ions are essential trace elements in the human body, which play an important role in human health, especially the catalytic auxiliary role in various biological processes such as the function of many cellular enzymes and proteins [10-12]. However, when the concentration of absorbed ions is unbalanced, the homeostasis in cells will be affected, leading to a series of diseases [13-15]. The multifunctional detection of the same sensor for each detection object is attracting attention due to its high efficiency [16-19]. As a result, the design and synthesis of new multifunctional fluorescent probes that can simultaneously detect copper and zinc ions are of great significance in biomedical and environmental monitoring applications $[20,21]$.

According to the structural characteristics of the analyte, the design of fluorescent molecules is crucial. Specific recognition units are introduced, such as $\mathrm{N}$-containing 
heterocyclic compounds such as quinoline [22], imidazole [23,24], and carbazole [25], to provide a definite binding site for metal ion as analyte. Using the availability, strong polarization, and $\pi-\pi$ electron transition function of the conjugate system to ensure its energy transfer or electron transfer [26], the multifunctional probe may be constructed. In addition, as an effective method to achieve fluorescence probe regulation $[27,28]$, the introduction of a long alkyl chain at the end of the compound increases the spatial effect of the polymer, significantly affecting the HOMO energy level, keeping the LUMO energy level basically unchanged, increasing the band gap [29], and affecting its optical properties, which is of great research value [30-32].

Herein, we used (E)-2-butenedioic acid (E-BA) as a "bridge" by two steps to synthesize a novel conjugated nanosphere structure polybenzimidazole sensor $\mathbf{C P B I}_{n}$ (Scheme 1), which can be used for $\mathrm{Cu}^{2+}$ and $\mathrm{Zn}^{2+}$ detection with fluorescence regulation. Additionally, through infrared spectrum (IR), X-ray photoelectron spectroscopy (XPS), scanning electron microscope (SEM), etc., their structures and photophysical properties were studied. The results show that $\mathrm{CPBI}_{n}$ with good solubility and optical properties can be successfully obtained by modifying $\mathbf{C P B I}_{0}$ with an alkyl chain and used as a multifunctional fluorescent probe to detect $\mathrm{Cu}^{2+}$ and $\mathrm{Zn}^{2+}$ at the same time, with a low detection limit.<smiles>Nc1ccc(-c2ccc(N)c(N)c2)cc1N</smiles>

1<smiles>O=C(O)/C=C/C(=O)O</smiles>

2

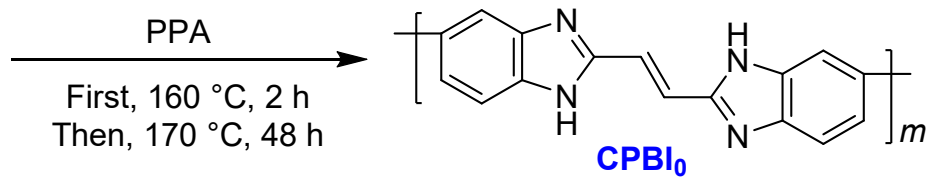

Then, $170^{\circ} \mathrm{C}, 48 \mathrm{~h}$
$\mathrm{CPBI}_{0}$

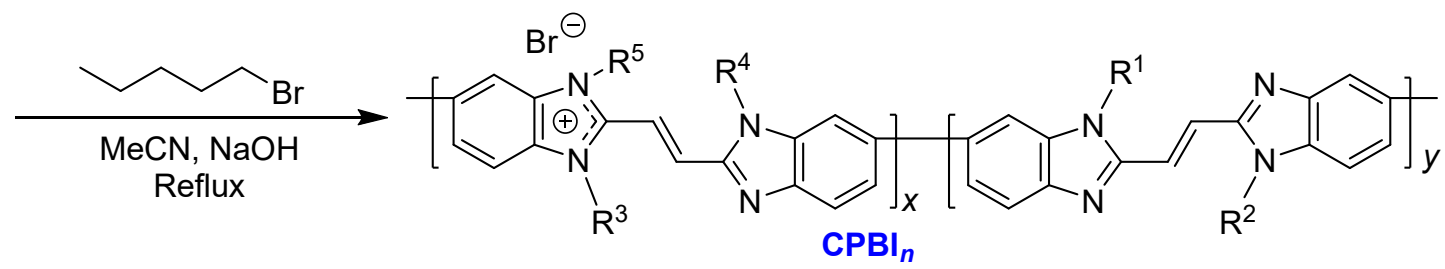

Scheme 1. Synthesis of serial CPBIs fluorescent materials.

\section{Materials and Methods}

2.1. Apparatus and Reagents

All reagents and organic solvents were purchased from commercial suppliers and used without further purification. ${ }^{1} \mathrm{H}$ NMR spectra of compounds were recorded on a Bruker $600 \mathrm{MHz}$ instrument (Bruker AVANCE NEO, Bruker, Karlsruhe, Germany). Fluorescence spectra were carried out by a Hitachi F-4600 fluorescence spectrometer (Hitachi, Tokyo, Japan). The Scanning Electron Microscope was obtained by FEI Quanta 250 FEG field emission scanning electron microscope (FEI Quanta 250 FEG, FEI, Hillsboro, OR, USA). The TG data were obtained by TG-209 F3 TG analyzer (NETZSCH-Gerätebau GmbH, Selb, Germany). Quantum yields were calculated by using quinine sulfate $\left(\Phi_{\mathrm{fl}}\right) 0.55$ in $0.5 \mathrm{M} \mathrm{H}_{2} \mathrm{SO}_{4}$ solution as a standard. Fluorescence lifetime spectrum was obtained using time-correlated single-photon counting method.

\subsection{Synthesis}

\subsubsection{Synthesis of Intermediate $\mathbf{C P B I}_{\mathbf{0}}$}

According to the literature [33-35], $20 \mathrm{~mL}$ polyphosphoric acid (PPA) and 3,3'-diamino benzidine 1 were added into a $50 \mathrm{~mL}$ flask and heated at $160^{\circ} \mathrm{C}$ for $2 \mathrm{~h}$. After they were completely dissolved, $3.0 \mathrm{mmol}$ trans-butenedioic acid (E-BA) 2 was added, and the mixture was heated to $170{ }^{\circ} \mathrm{C}$ for $48 \mathrm{~h}$. After cooling to room temperature, the $\mathrm{pH}$ was adjusted to alkaline with $\mathrm{NaOH}$ solution, and then a blue-black solid was obtained by the filtration. 


\subsubsection{Synthesis of Series of $\mathbf{C P B I _ { n }}$}

According to reported methods [36-38], 1 mmol $\mathbf{C P B I}_{0}$, different molar $n-\mathrm{C}_{5} \mathrm{H}_{11} \mathrm{Br}$ (Table 1), $10 \mathrm{~mL} \mathrm{MeCN}$, and moderate $\mathrm{NaOH}$ were added into the reaction flask. After refluxing for $24 \mathrm{~h}$, the organic solvent was evaporated in vacuo. The crude product was washed several times with plenty of water to remove $\mathrm{NaOH}$, and then the alkylation product was treated with a mixture of methylene chloride and ethanol. Once the organic phase was collected continuously, the solvent was removed in vacuo. After the desired product was dried in a vacuum drying oven at $40^{\circ} \mathrm{C}$ for $24 \mathrm{~h}$, the purified soluble alkylation solid product $\mathbf{C P B I}_{n}$ was obtained.

Table 1. The effects of different feed ratios on the basic structure of serial $\mathbf{C P B I}_{n}$.

\begin{tabular}{ccccccc}
\hline Sample & $\begin{array}{c}\text { Feed Ratio } \\
(\mathbf{R B r} / \mathbf{C P B I} \mathbf{0})\end{array}$ & \multicolumn{1}{c}{$\mathbf{R}^{\mathbf{1}}$} & \multicolumn{1}{c}{$\mathbf{R}^{\mathbf{2}}$} & $\mathbf{R}^{\mathbf{3}}$ & $\mathbf{R}^{\mathbf{4}}$ & $\mathbf{R}^{\mathbf{5}}$ \\
\hline $\mathbf{C P B I}_{\mathbf{1}}$ & $1: 1$ & $n-\mathrm{C}_{5} \mathrm{H}_{11^{-}}$ & $\mathrm{H}$ & $n-\mathrm{C}_{5} \mathrm{H}_{11^{-}}$ & $\mathrm{H}$ & - \\
$\mathbf{C P B I}_{\mathbf{2}}$ & $2: 1$ & $n-\mathrm{C}_{5} \mathrm{H}_{11^{-}}$ & $n-\mathrm{C}_{5} \mathrm{H}_{11^{-}}$ & $n-\mathrm{C}_{5} \mathrm{H}_{11^{-}}$ & $\mathrm{H}$ & - \\
$\mathbf{C P B I}_{3}$ & $3: 1$ & $n-\mathrm{C}_{5} \mathrm{H}_{11^{-}}$ & $n-\mathrm{C}_{5} \mathrm{H}_{11^{-}}$ & $n-\mathrm{C}_{5} \mathrm{H}_{11^{-}}$ & $\mathrm{H}$ & - \\
$\mathbf{C P B I}_{4}$ & $4: 1$ & $n-\mathrm{C}_{5} \mathrm{H}_{11^{-}}$ & $n-\mathrm{C}_{5} \mathrm{H}_{11^{-}}$ & $n-\mathrm{C}_{5} \mathrm{H}_{11^{-}}$ & $n-\mathrm{C}_{5} \mathrm{H}_{11^{-}}$ & $n-\mathrm{C}_{5} \mathrm{H}_{11^{-}}$ \\
$\mathbf{C P B I}_{\mathbf{5}}$ & $5: 1$ & $n-\mathrm{C}_{5} \mathrm{H}_{11^{-}}$ & $n-\mathrm{C}_{5} \mathrm{H}_{11^{-}}$ & $n-\mathrm{C}_{5} \mathrm{H}_{11^{-}}$ & $n-\mathrm{C}_{5} \mathrm{H}_{11^{-}}$ & $n-\mathrm{C}_{5} \mathrm{H}_{11^{-}}$ \\
$\mathbf{C P B I}_{\mathbf{6}}$ & $6: 1$ & $n-\mathrm{C}_{5} \mathrm{H}_{11^{-}}$ & $n-\mathrm{C}_{5} \mathrm{H}_{11^{-}}$ & $n-\mathrm{C}_{5} \mathrm{H}_{11^{-}}$ & $n-\mathrm{C}_{5} \mathrm{H}_{11^{-}}$ & $n-\mathrm{C}_{5} \mathrm{H}_{11^{-}}$ \\
$\mathbf{C P B I}_{\mathbf{7}}$ & $7: 1$ & $n-\mathrm{C}_{5} \mathrm{H}_{11^{-}}$ & $n-\mathrm{C}_{5} \mathrm{H}_{11^{-}}$ & $n-\mathrm{C}_{5} \mathrm{H}_{11^{-}}$ & $n-\mathrm{C}_{5} \mathrm{H}_{11^{-}}$ & $n-\mathrm{C}_{5} \mathrm{H}_{11^{-}}$ \\
\hline
\end{tabular}

\section{Results}

\subsection{Structural Characterization and Basic Properties of CPBIs}

The structures of $\mathrm{CPBI}_{\text {S }}$ were characterized by ${ }^{1} \mathrm{H}$ NMR, IR, XPS, etc. As shown in Figure 1 (see SM for more detailed characterization data of all CPBIs from Figures S1-S7), it can be found that, with the $\mathrm{N}$-alkylation reaction, the signal of $\mathrm{N}-\mathrm{H}\left(\mathrm{H}_{d}, 13.03 \mathrm{ppm}\right)$ in the main chain of $\mathbf{C P B I} \mathbf{I}_{0}$ is becoming weak for the gradual replacement. At the same time, new signals of alkyl chain characteristics, such as $\mathrm{H}_{f}(4.06 \sim 4.55 \mathrm{ppm}), \mathrm{H}_{g}(1.58 \sim 1.65 \mathrm{ppm})$, $\mathrm{H}_{i}, \mathrm{H}_{h}(1.23 \sim 1.28 \mathrm{ppm})$, and $\mathrm{H}_{j}(0.686 \sim 0.90 \mathrm{ppm})$, can be observed in $\mathbf{C P B I}_{n}$ (Figure S7). In addition, the signal of terminal olefin double bond hydrogen $(=\mathrm{CH}, 6.32-6.67 \mathrm{ppm})$ in the polymer was used to calculate the number-average molecular weight $\left(\mathrm{M}_{\mathrm{n}}\right)$ of $\mathrm{CPBI}_{n}$. As shown in Table S1, it can be seen that, with the increase of the feed ratio of $n\left(\mathrm{C}_{5} \mathrm{H}_{11} \mathrm{Br}\right) / n\left(\mathbf{C} \mathbf{P B I} \mathbf{I}_{0}\right)$, the alkylation rate of $\mathbf{C P B I}{ }_{n}$ increases continuously and the $\mathbf{M}_{n}$ also increases correspondingly, which is consistent with expectations. Meanwhile, the color of solid product is gradually lightening (Table S1).

In the FT-IR spectra, with the increase of feed ratio $\left[n\left(\mathrm{C}_{5} \mathrm{H}_{11} \mathrm{Br}\right) / n\left(\mathbf{C P B I} \mathbf{I}_{\mathbf{0}}\right)\right]$, the benzimidazole N-H stretching vibration at $3300 \mathrm{~cm}^{-1}$ is gradually decreased. On the contrary, some characteristic stretching vibrations of saturated alkyl chains at 2984, 2853, 1479, and $730 \mathrm{~cm}^{-1}$ are strengthened continuously. Of course, the $\mathrm{C}-\mathrm{N}$ stretching vibration at $1325 \mathrm{~cm}^{-1}$ is also gradually enhanced (Figure S8). These all indicate that the $N$-alkylation reaction has successfully attached the alkyl chain to the polymer via $\mathrm{C}-\mathrm{N}$ bond.

As reference method [39-41], the XPS energy spectra of $\mathbf{C P B I}_{2}$ shown in Figure S9 were analyzed. It can be seen from Figure S9a that 284.76, 399.76, and $531.76 \mathrm{eV}$ are attributed to $\mathrm{C} 1 \mathrm{~s}, \mathrm{~N} 1 \mathrm{~s}$, and $\mathrm{O} 1 \mathrm{~s}$ on the $\mathbf{C P B I}_{2}$ skeleton, respectively. The sub-peaks of $\mathrm{C} 1 \mathrm{~s}$ are $284.865 \mathrm{eV}, 284.346 \mathrm{eV}, 285.982 \mathrm{eV}$, and $287.795 \mathrm{eV}$, respectively, belonging to $\mathrm{C}-\mathrm{C} / \mathrm{C}=\mathrm{C}$, $\mathrm{C}-\mathrm{N} / \mathrm{C}-\mathrm{O}, \mathrm{C}=\mathrm{N}$, and the polymer terminal $\mathrm{C}=\mathrm{O}$ (Figure $\mathrm{S} 9 \mathrm{~b}$ ). The electron energies of $\mathrm{C}-\mathrm{N}$ and $\mathrm{C}=\mathrm{N}$ can also be obtained from the sub-peaks of N1s (Figure S9c). Thus, the XPS data further demonstrate the construction of the polymer skeleton. In a word, $\mathbf{C P B I}_{\mathbf{0}}$ has been successfully $\mathrm{N}$-alkylated, which is proved by ${ }^{1} \mathrm{H}$ NMR, IR, and XPS. Additionally, changing the feed ratio $\left[n\left(\mathrm{C}_{5} \mathrm{H}_{11} \mathrm{Br}\right) / n\left(\mathbf{C} \mathbf{P B I _ { 0 }}\right)\right], \mathbf{C} \mathbf{P B I} \mathbf{I}_{n}$ polymers with different alkylation degrees can be obtained, as shown in Table S1. Subsequently, SEM, TG, and XRD of $\mathbf{C P B I}_{n}$ were studied and discussed. 


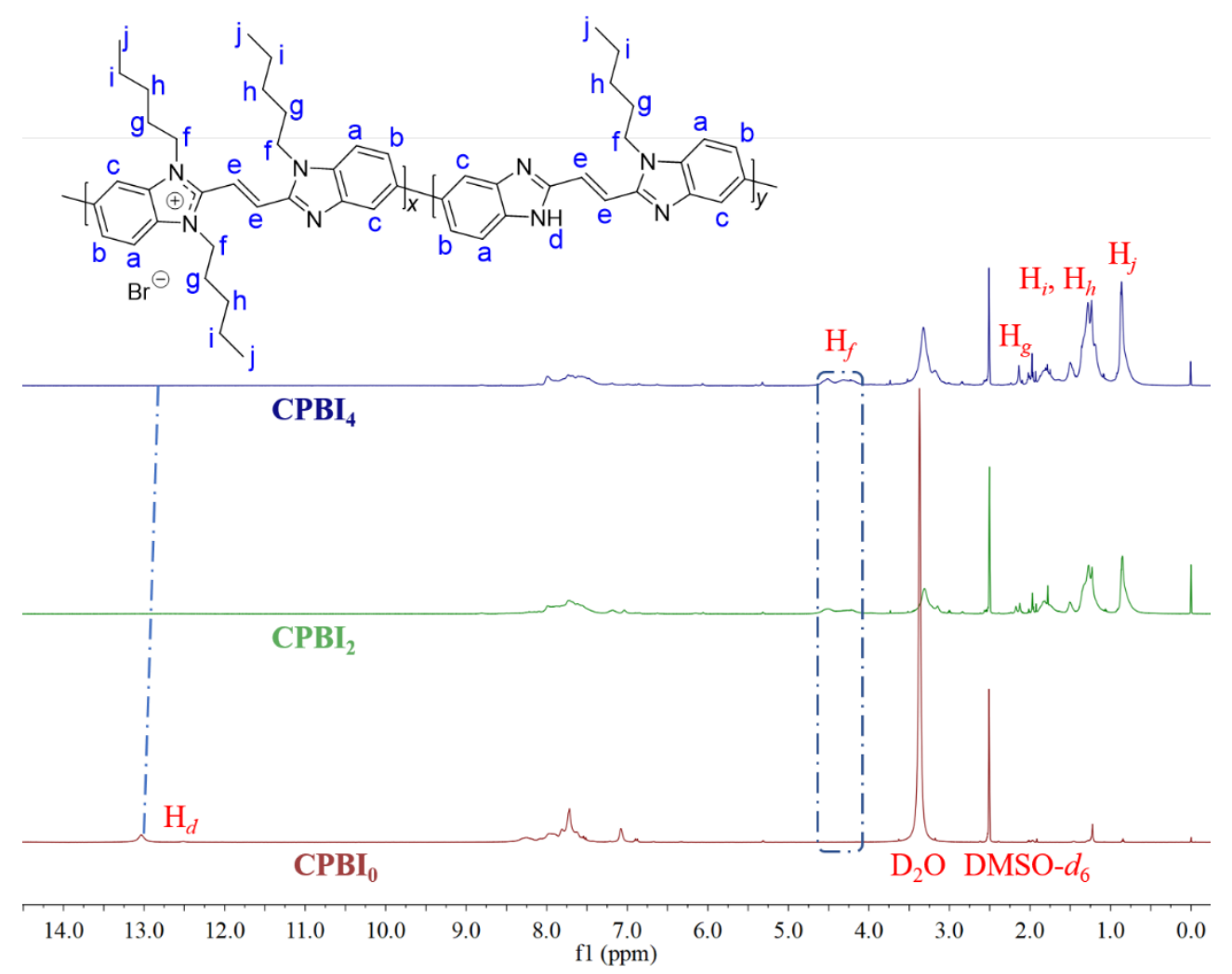

Figure 1. The changes of ${ }^{1} \mathrm{H}$ NMR spectra of $\mathbf{C P B I}_{0}$ and $\mathbf{C P B I} \mathbf{I}_{n}$.

The crystallization performance of serial CPBIs was analyzed by XRD (Figure S10). Under low alkylation rate $\left(\mathbf{C P B I}_{\mathbf{1}} \sim \mathbf{C P B I}_{4}\right)$, the polymer is amorphous. However, with the continuous increase of alkylation rate $\left(\mathbf{C P B I}_{5} \sim \mathrm{CPBI}_{7}\right)$, the polymer morphology tends to become regular, and the crystallinity is increased (Figure S10b). The thermal stabilities of the CPBIs were investigated under an $\mathrm{O}_{2}$ atmosphere (Figure S11). The initial and termination temperatures of thermal decomposition of $\mathbf{C P B I}_{5} \sim \mathrm{CPBI}_{7}$ polymers with high alkylation rate (Table S1) and certain crystallinity are significantly higher than those of amorphous $\mathrm{CPBI}_{1} \sim \mathrm{CPBI}_{4}$ polymers with low alkylation rate (Table S2, and the detailed data analysis can be seen in SM).

Using reported method [42-44], SEM was used to observe the morphology of series CPBIs, as shown in Figure S12. The surface of $\mathbf{C P B I}_{\mathbf{0}}$ is flat and lamellar. When the feed ratio $\left[n\left(\mathrm{C}_{5} \mathrm{H}_{11} \mathrm{Br}\right) / n\left(\mathbf{C P B I}_{0}\right)\right]$ is $1 / 1$, the original lamellar structure is destroyed and gradually transferred to the nano-microsphere structure. When the feed ratio is $2 / 1$, $\mathbf{C P B I}_{2}$ has a nano-microsphere structure with a diameter of $375 \mathrm{~nm}$ (Figure 2a). With the continuous increase of alkylation rate, there is still nanosphere structure, e.g., $\mathrm{CPBI}_{4}$ with a diameter of $323 \mathrm{~nm}$ (Figure $2 \mathrm{~b}$ ). When $n\left(\mathrm{C}_{5} \mathrm{H}_{11} \mathrm{Br}\right) / n\left(\mathbf{C} \mathbf{P B I}_{0}\right)$ is equal to or bigger than $5: 1$, the nanosphere becomes a larger microsphere (e.g., $\mathbf{C P B I}_{5}$ with a diameter of $7 \mu \mathrm{m}$ ), and begins to be destroyed and accumulated (see Figure S12 in SM). This may be due to the electrostatic repulsion of the polymers being different with the increase of the alkylation rate during the $\mathrm{N}$-alkylation process of $\mathbf{C P B I}_{\mathbf{0}}$ and the size of microspheres formed by these polymers under the influence of different electrostatic forces. Therefore, not only can the alkylation rate of $\mathbf{C P B I}_{0}$ be regulated by the feed ratio of reactants, but also, the morphology of the alkylation product can be adjusted, and the nanosphere structure may be formed when the ratio is appropriate (Figure 2). 

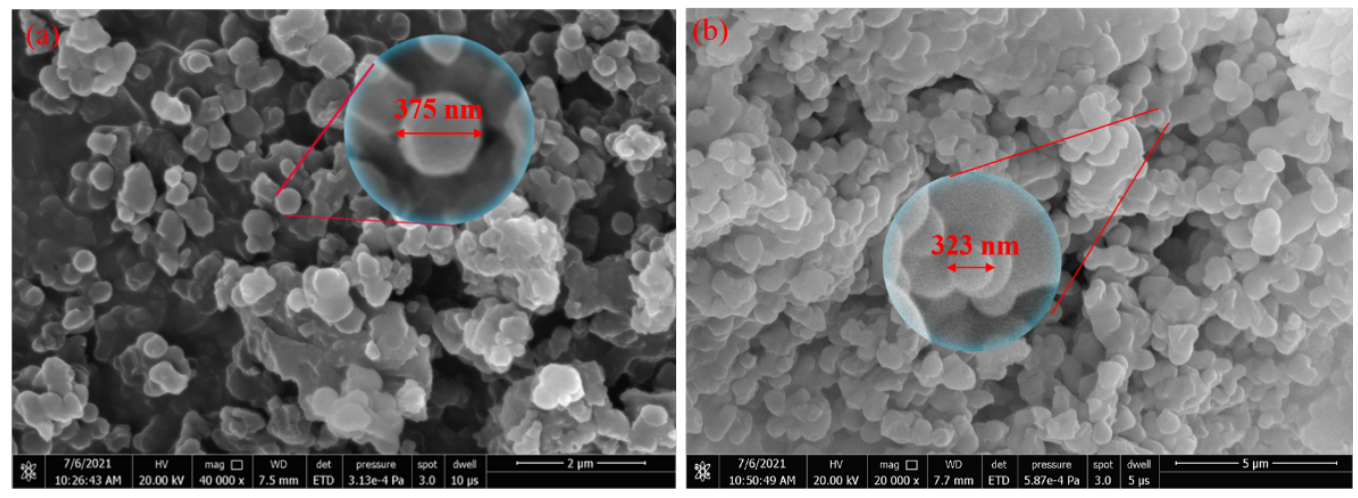

Figure 2. SEM imgaes of $\mathrm{CPBI}_{2}(\mathbf{a})$ and $\mathrm{CPBI}_{4}(\mathbf{b})$.

\subsection{The Photophysical Properties of Serial CPBIs}

As an electron-donating group, the alkyl chain easily produces a $\mathrm{p}-\pi$ conjugate with the benzene ring, resulting in enhanced fluorescence of the probe [31]. In addition, for conjugated polymers, the Aggregation-Caused Quenching (ACQ) effect is weakened by the introduction of long alkyl chains. This improves the solid-state fluorescence of the polymer. In order to illustrate the effect of alkylation rate on the fluorescence intensity of the polymer, the fluorescence test of $\mathbf{C P B I}_{n}$ in solid and liquid was carried out, respectively, as shown in Figure 3. It can be found that the fluorescence of solid-state $\mathbf{C P B I}{ }_{n}$ is greatly influenced by the alkylation rate, and its fluorescence emission intensity increases with the increase of the alkylation rate (Figure 3a). With a significant blue shift, the solid fluorescence color changes from orange-yellow to yellow (Figure $3 \mathrm{c}$ and Table S3).
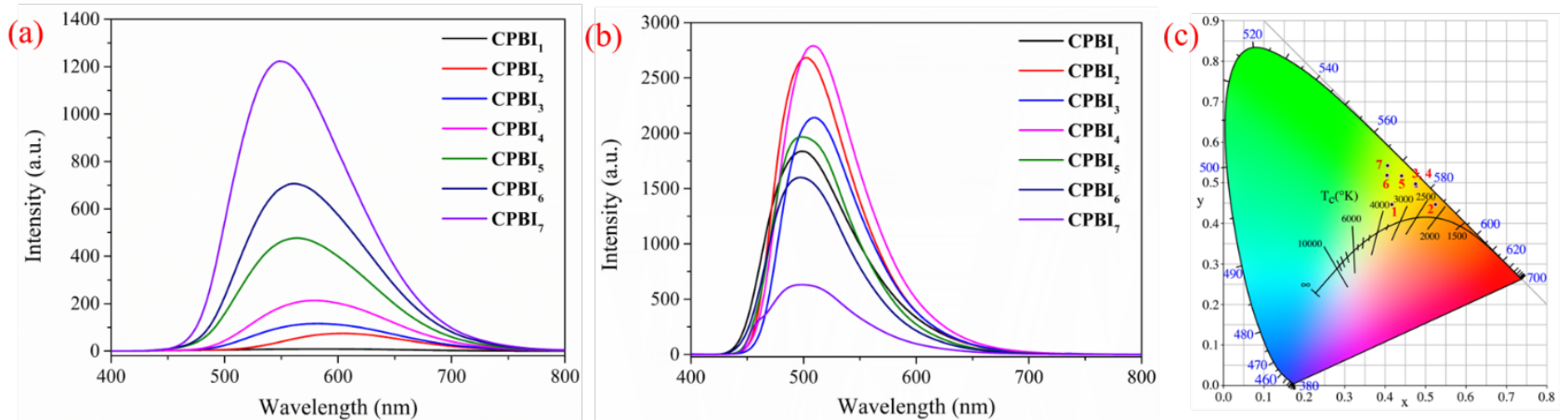

Figure 3. Solid fluorescence emission spectra (a), liquid fluorescence emission spectra ( $1 \mathrm{mg} / 15 \mathrm{~mL}$ in DMSO, $\left.\lambda_{\mathrm{ex}}=375 \mathrm{~nm}\right)$ (b), and solid chromaticity diagram of $\mathbf{C P B I}_{n}$ with different feeding ratios (c).

Usually, the use of large conjugated polybenzimidazole in the probe field is limited because of solubility. Here, we modified $\mathbf{C P B I}_{0}$ by $N$-alkylation to obtain a series of new polymer $\mathbf{C} \mathbf{P B I}{ }_{n}$. These polymers (especially $\mathbf{C} \mathbf{P B I}_{\mathbf{1}} \sim \mathbf{C} \mathbf{P B I}_{4}$ ) are soluble in a variety of organic solvents, such as THF, DMF, DMSO, etc. Among them, DMSO has the best solubility, so DMSO is used as the solvent in the subsequent fluorescence tests. In Figure $3 \mathrm{~b}$, it can be found that the fluorescence intensity of $\mathbf{C P B I}_{n}$ solution is not only affected by the electron donation of alkyl chain but also greatly related to its structure, solubility, and molecular vibration $[32,45,46]$. Therefore, there is no obvious regular change in the fluorescence intensity of their solution. Even so, among them, $\mathbf{C P B I}_{2}$ and $\mathbf{C P B I}_{\mathbf{4}}$ have relatively strong fluorescence, which may be determined by their nanosphere structure (Figure 2).

The effects of different solvents such as THF, MeCN, EtOH, DMF, DMSO, $\mathrm{CH}_{2} \mathrm{Cl}_{2}$, and $\mathrm{CHCl}_{3}$ on the fluorescence properties of the polymer were also investigated. The experimental results are shown in Figure S13. It can be seen that, in different solvents, the difference in fluorescence intensity of $\mathbf{C P B I}_{1} \sim \mathbf{C P B I}_{4}$ is mainly affected by solubility rather 
than solvent polarity. Additionally, the position of the fluorescence emission peak of $\mathbf{C P B I}_{n}$ has little relation with the polarity of the solvent.

The metal ions are soluble in water, and they are generally tested in the experiments as salt solutions. In order to eliminate the influence of the presence of water on the detection of metal ions, the changes in the fluorescence intensity of $\mathbf{C} \mathbf{P B I}_{\mathbf{1}} \sim \mathbf{C P B I}_{4}$ with different water content were studied (Figure S14). With the increase of water content as DMSO/ $\mathrm{H}_{2} \mathrm{O}(v / v)$, the fluorescence emission intensity of $\mathbf{C P B I}_{n}$ is decreased sharply and basically reaches complete quenching (ACQ) at 50\% water content $(50: 50, v / v)$. Therefore, to avoid the interference of higher water content, $\mathrm{DMSO} / \mathrm{H}_{2} \mathrm{O}(90: 10, v / v)$ is used as the mixed solvent in the following experiments to study the sensing performance of the polymer towards metal ions.

\subsection{Sensing Performance of $C P B I_{n}$ towards Metal Ions}

The solubility and photophysical properties of $\mathbf{C P B I}_{0}$ are improved by $N$-alkylation reaction. In DMSO $/ \mathrm{H}_{2} \mathrm{O}(90: 10, v / v)$ solvents, the effect of alkylation rate on the fluorescence properties of the polymer was analyzed by studying the corresponding $\mathbf{C P B I}_{n}$ to different metal ions. The selectivity of $\mathbf{C P B I}_{2}$ (37.4\% alkylation) for 18 metal ions was investigated in $\mathrm{DMSO} / \mathrm{H}_{2} \mathrm{O}$ system. Only $\mathrm{Cu}^{2+}$ and $\mathrm{Zn}^{2+}$ are tightly bound by probe $\mathbf{C P B I}_{2}$, resulting in the fluorescence quenching of $\mathbf{C P B I}_{2}$ at $\lambda_{\mathrm{em}}=504 \mathrm{~nm}$ with the excitation at $375 \mathrm{~nm}$ (Figure $4 \mathrm{a}$ ), and the fluorescence quenching rate is $89.4 \%$ and $91.5 \%$, respectively. Compared with the response of $\mathrm{Cu}^{2+}$, after the addition of $\mathrm{Zn}^{2+}$, the fluorescence color of $\mathrm{CPBI}_{2}$ probe solution is changed from bright green to yellow under $365 \mathrm{~nm}$ UV light (Figure 4c), and $\lambda_{\mathrm{em}}$ is red-shifted from $504 \mathrm{~nm}$ to $519 \mathrm{~nm}$. For the other metals evaluated, only $\mathrm{Fe}^{3+}$ has a slightly similar effect, but this can be negligible in comparison with $\mathrm{Cu}^{2+}$ and $\mathrm{Zn}^{2+}$ (Figure $4 \mathrm{~b}$ ). Therefore, $\mathbf{C P B I}_{2}$ can be used as a "turn-off" probe for the simultaneous detection of $\mathrm{Cu}^{2+}$ and $\mathrm{Zn}^{2+}$.
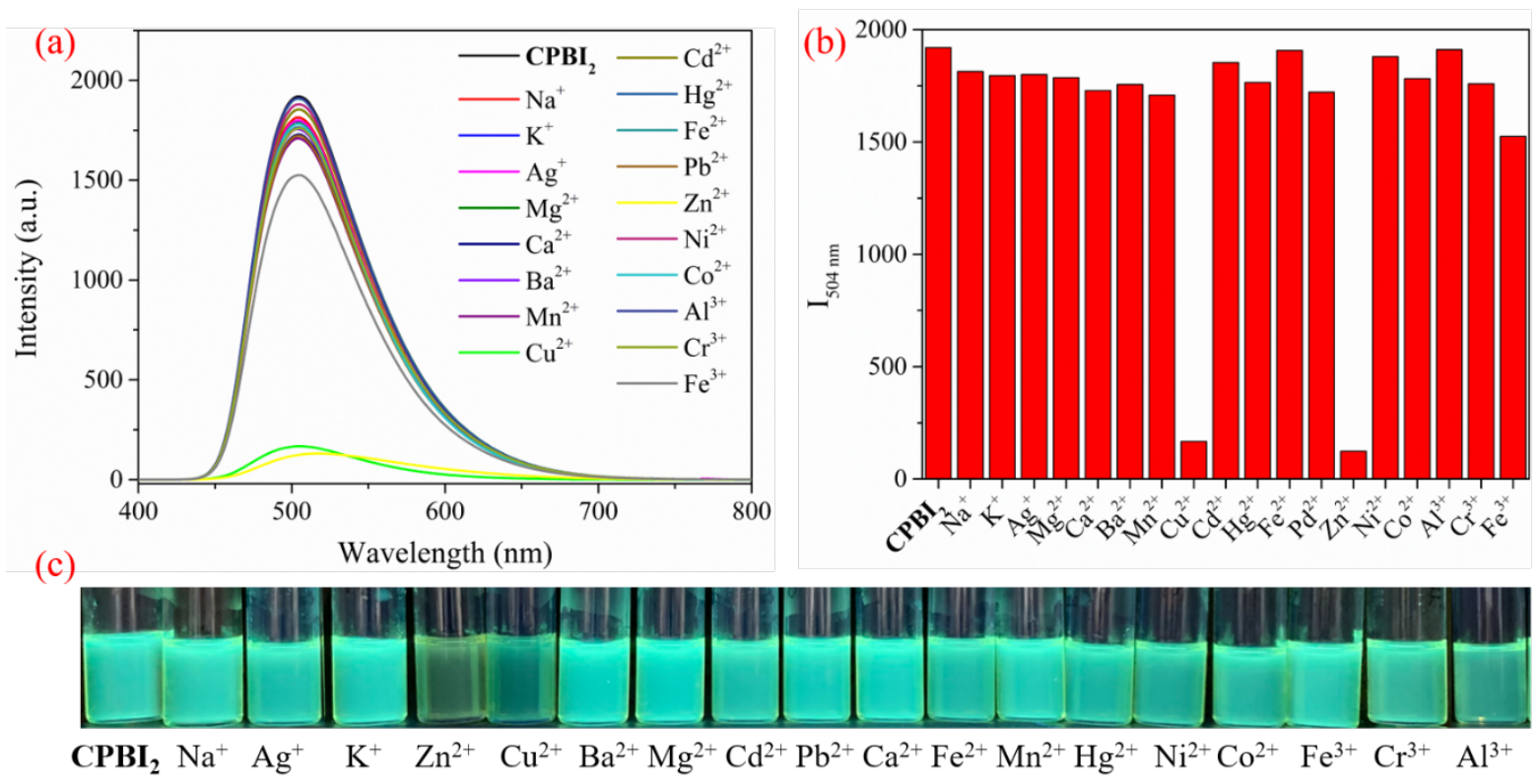

Figure 4. The fluorescence selectivity study of different metal ions $(100 \mu \mathrm{M})$ in $\mathbf{C P B I}_{2}\left(1 \mathrm{mg} / 15 \mathrm{~mL}\right.$ in $\mathrm{DMSO} / \mathrm{H}_{2} \mathrm{O}, v / v$, 9/1) solution, $\lambda_{\mathrm{ex}}=375 \mathrm{~nm}(\mathbf{a})$; the influence of adding different metal ions $(100 \mu \mathrm{M})$ on $\mathbf{C P B I}_{2}$ fluorescence intensity at $504 \mathrm{~nm}$ (b); and the fluorescence color change of the solution when different metal ions are added under a $365 \mathrm{~nm}$ UV $\operatorname{lamp}(\mathbf{c})$.

We also studied the possibility of other common metal ions interfering with the detection of $\mathrm{Cu}^{2+}$ and $\mathrm{Zn}^{2+}$. As seen in Figure S15, the presence of other metal ions has no effect on the detection of $\mathrm{Cu}^{2+}$ and $\mathrm{Zn}^{2+}$ by the probe $\mathbf{C P B I}_{2}$. The results show that $\mathbf{C P B I}_{2}$ has good anti-interference ability for the detection of $\mathrm{Cu}^{2+}$ and $\mathrm{Zn}^{2+}$. The fluorescence 
intensity of $\mathbf{C P B I}_{2}$ is gradually decreased at $\lambda_{\mathrm{em}}=504 \mathrm{~nm}$ with the addition of $\mathrm{Cu}^{2+}$ and $\mathrm{Zn}^{2+}(0 \sim 100 \mu \mathrm{M})$, as shown in Figure 5a,c. According to the calculation method reported in the literature [47-49], the fluorescence detection limit of sensor $\mathbf{C P B I}_{\mathbf{2}}$ for $\mathrm{Cu}^{2+}$ and $\mathrm{Zn}^{2+}$ can be calculated as $5.98 \times 10^{-9} \mathrm{M}$ and $6.02 \times 10^{-9} \mathrm{M}$, respectively (Figure $5 \mathrm{~b}, \mathrm{~d}$ ). Compared with the data reported before, the results indicate that sensor $\mathbf{C P B I}_{\mathbf{2}}$ is more sensitive than most known $\mathrm{Cu}^{2+}$ and $\mathrm{Zn}^{2+}$ sensors [50-54] (more comparisons can be seen in Tables S5 and S6).
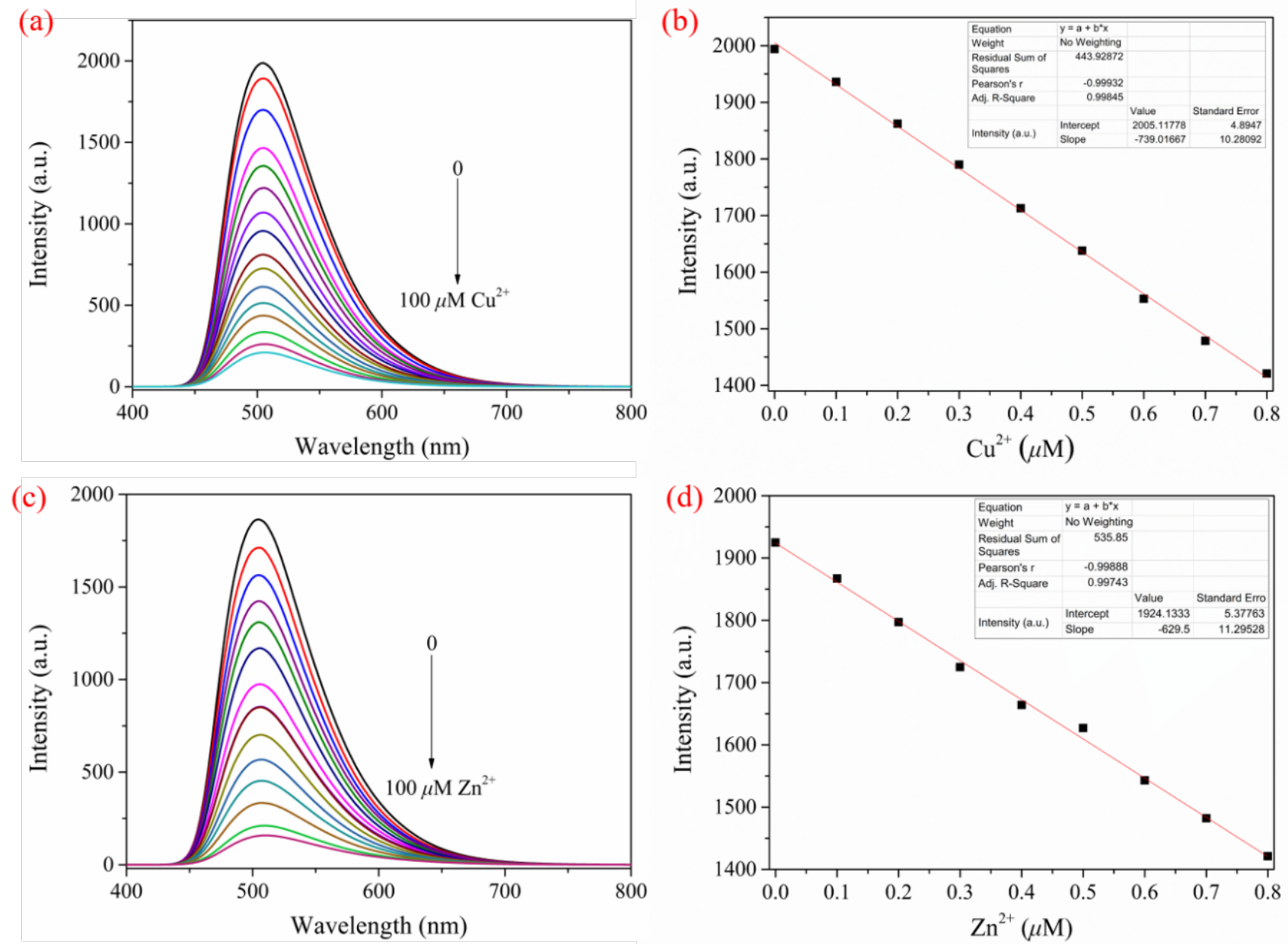

Figure 5. Fluorescence titration of $\mathbf{C P B I}_{2}\left(1 \mathrm{mg} / 15 \mathrm{~mL}\right.$ in DMSO/ $\left.\mathrm{H}_{2} \mathrm{O}, v / v, 9 / 1\right)$ solution with $\mathrm{Cu}^{2+}(\mathbf{a}, \mathbf{b}), \mathrm{Zn}^{2+}(\mathbf{c}, \mathbf{d})$, and their corresponding detection limits $\left(\lambda_{\mathrm{ex}}=375 \mathrm{~nm}\right)$.

In addition, as a "turn-off" fluorescence sensor, the fluorescence-quenching process of $\mathbf{C P B I}_{2}$ can be determined by Stern-Volmer (S-V) constant (Ksv), whose calculation formula is: $\mathrm{I}_{0} / \mathrm{I}=1+\mathrm{Ksv}[\mathrm{Q}]$ (Figure 6). The $\mathrm{S}-\mathrm{V}$ curve has a tendency to bend upward when a higher concentration of $\mathrm{Cu}^{2+}$ or $\mathrm{Zn}^{2+}$ is added to $\mathbf{C} \mathbf{P B I} \mathbf{I}_{2}$ solution. However, the Stern-Volmer equation has a linear-fitting relationship when the concentration of metal ions is lower. This indicates that there are static and dynamic quenching processes of $\mathbf{C P B I}_{2}$ interaction with metal ions. $\mathrm{Ksv}$ values for $\mathbf{C P B I}_{2}$ towards $\mathrm{Cu}^{2+}$ and $\mathrm{Zn}^{2+}$ can be calculated to be $8.95 \times 10^{4}$ and $4.52 \times 10^{4} \mathrm{M}^{-1}$, respectively. Fluorescence sensors with dynamic quenching may show good reversibility detection for metal ions $[55,56]$. 

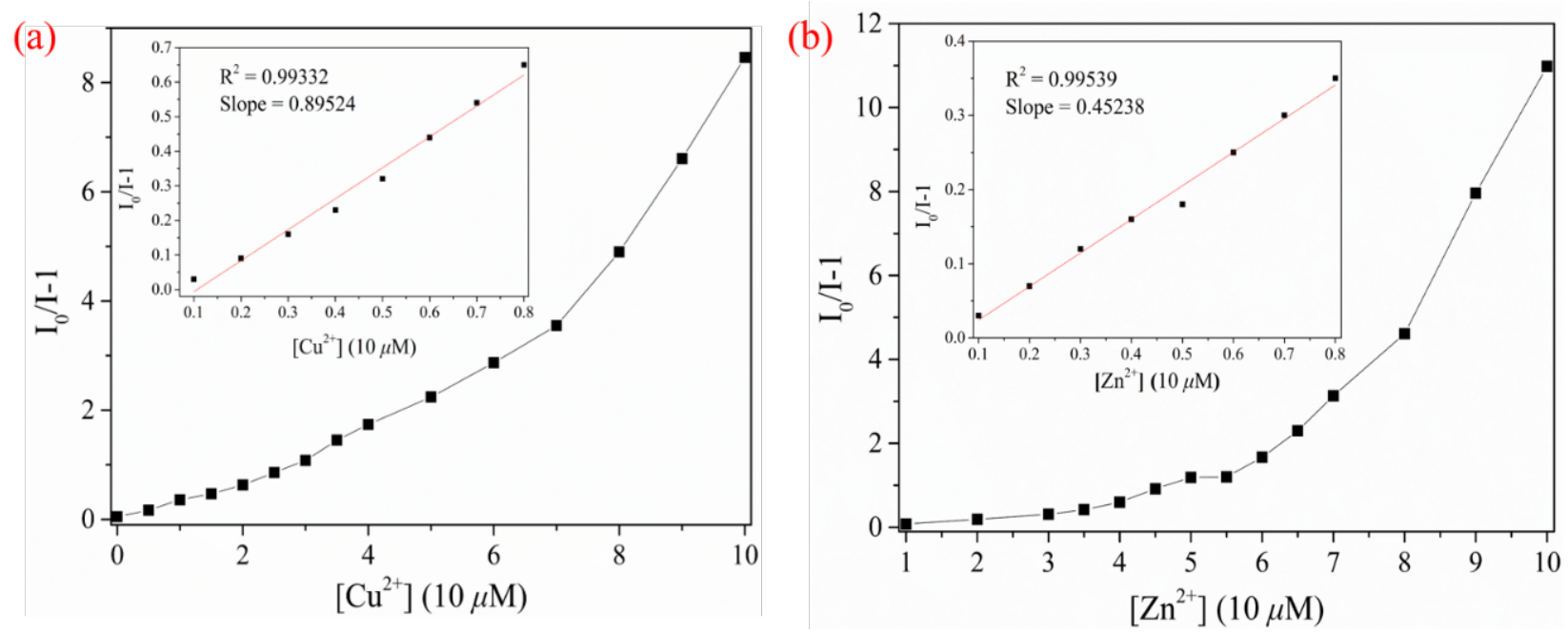

Figure 6. Stern-Volmer diagram of the interaction of sensors $\mathbf{C P B I}_{2}$, with $\mathrm{Cu}^{2+}(\mathbf{a})$ and $\mathrm{Zn}^{2+}(\mathbf{b})$ (the illustration shows the Stern-Volmer linear diagram at low concentrations).

Similarly, we also conducted the fluorescence tests on other alkylated polymers, such as $\mathbf{C P B I}_{1}, \mathbf{C P B I}_{3}$, and $\mathbf{C P B I}$, as shown in Figures S16-S28. As anticipated, $\mathbf{C P B I}_{1}$, $\mathrm{CPBI}_{3}$, and $\mathrm{CPBI}_{4}$ can selectively recognize $\mathrm{Cu}^{2+}$ and $\mathrm{Zn}^{2+}$ (Figures S16, S20, and S24). For example, it can be found that the Stern-Volmer equation of $\mathbf{C P B I}_{4}$ has a good linear relationship with the concentration of metal ions (Ksv values for $\mathbf{C P B I}_{4}$ towards $\mathrm{Cu}^{2+}$ and $\mathrm{Zn}^{2+}$ can be calculated to be $2.20 \times 10^{4}$ and $1.45 \times 10^{4} \mathrm{M}^{-1}$, respectively), so the fluorescence quenching mode of $\mathbf{C P B I}_{4}$ is static quenching (Figure S28).

Importantly, the sensitivity to metal ions is increasing with the increase of alkylation rate (Table S4). However, the fluorescence-quenching effect is decreasing. This may be due to the increase in electron-donating groups in the polymer as the alkylation rate increases, which makes it easier to combine with electron-deficient metal ions. Nevertheless, the steric hindrance of the polymer is increased likewise, and the combination of metal ions is reduced correspondingly when the alkylation rate is too high, so the fluorescence-quenching effect is reduced. This represents that the different alkylation rates will lead to the different detection performances of polymer fluorescent probes, which further demonstrates the regulation of alkyl chain on the performance of polymer fluorescent probes.

\subsection{Sensing Mechanism of CPBIs for Metal Ions}

According to the reported method [53,57-59], we explored the sensing mechanism of CPBIs before and after the interaction with analytes by IR, SEM, and DFT. Using $\mathbf{C P B I}_{2}$ as an example, in the IR spectra (Figure $7 \mathrm{a})$, the $\mathrm{C}=\mathrm{N}$ stretching vibration $\left(1654 \mathrm{~cm}^{-1}\right)$, $\mathrm{C}-\mathrm{N}$ stretching vibration $\left(1327 \mathrm{~cm}^{-1}\right)$, and $\mathrm{N}-\mathrm{H}$ stretching vibration of imidazole ring in probe $\mathbf{C P B I}_{2}$ are greatly weakened after the addition of $\mathrm{Cu}^{2+}$. This suggests that $\mathrm{Cu}^{2+}$ can interact with $\mathrm{C}=\mathrm{N}$ and not alkylated $\mathrm{C}-\mathrm{N}$ in the imidazole ring of the $\mathbf{C P B I}_{2}$ backbone. Of course, after complexing with metal ions, there is an aggregation for $\mathbf{C P B I}_{2}$, which limits the movement of the alkyl chain, resulting in an obvious weakening of the saturated C-H flexural vibration $\left(1461 \mathrm{~cm}^{-1}\right)$ also. Importantly, a new absorption can be observed at $1121 \mathrm{~cm}^{-1}$ when $\mathbf{C P B I}_{2}$ interacts with $\mathrm{Cu}^{2+}$. It is consistent with the results in the literature [16,60-62]. In addition, the results of SEM further demonstrate that the original nanoparticle structure of $\mathbf{C P B I}_{2}$ (Figure $7 \mathrm{~d}$ ) has aggregated into a massive flaky structure (Figure 7c) after the interaction of $\mathbf{C} \mathbf{P B I}_{2}$ with $\mathrm{Cu}^{2+}$. 


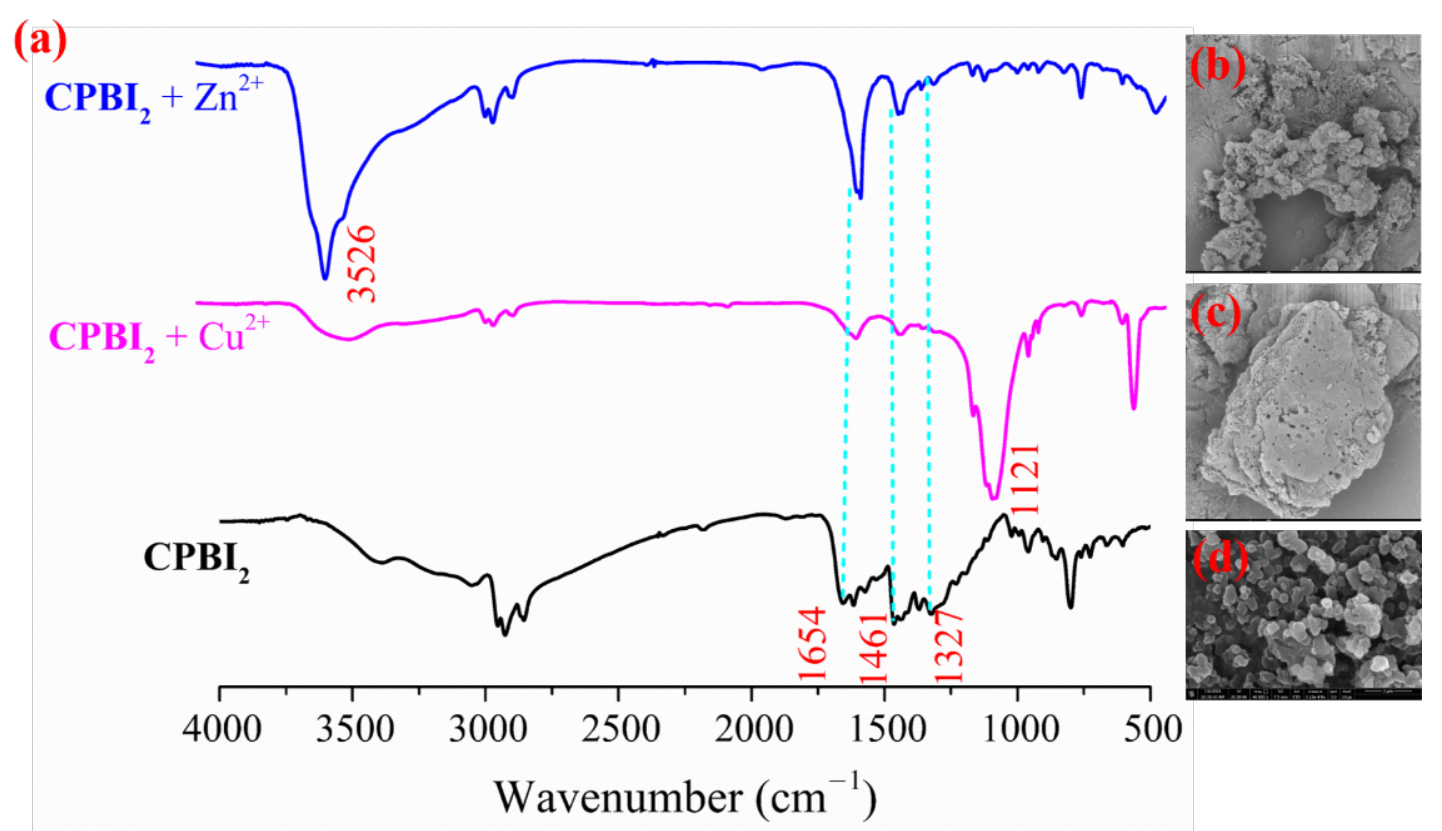

Figure 7. FT-IR spectra (a), SEM images of $\mathbf{C P B I}_{2}$ before and after the addition of $\mathrm{Cu}^{2+}$ or $\mathrm{Zn}^{2+}\left((\mathbf{b}): \mathbf{C P B I}_{2}+\mathrm{Zn}^{2+}\right.$; (c): $\left.\mathrm{CPBI}_{2}+\mathrm{Cu}^{2+} ;(\mathbf{d}): \mathrm{CPBI}_{2}\right)$.

Similarly, the C-N stretching vibration $\left(1327 \mathrm{~cm}^{-1}\right)$ of $\mathbf{C P B I}_{2}$ is also greatly weakened when $\mathbf{C P B I}_{2}$ interacts with $\mathrm{Zn}^{2+}$, while the $\mathrm{C}=\mathrm{N}$ stretching vibration intensity $\left(1654 \mathrm{~cm}^{-1}\right)$ is basically unchanged (Figure 7a). This shows that $\mathrm{Zn}^{2+}$ is mainly coordinated with $\mathrm{C}-\mathrm{N}$ in the main chain of benzimidazole. Additionally, the flexural vibration of alkyl chain (1461 $\mathrm{cm}^{-1}$ ) is also limited when coordinated with $\mathrm{Zn}^{2+}$. Moreover, a new absorption appears at $3540 \mathrm{~cm}^{-1}$, which is also consistent with the results in the literature [63,64]. At the same time, the image of SEM (Figure $7 \mathrm{~b}$ ) also shows the interaction between $\mathbf{C P B I}_{2}$ and $\mathrm{Zn}^{2+}$. Therefore, the interaction between $\mathrm{CPBI}_{2}$ and $\mathrm{Cu}^{2+}$ and $\mathrm{Zn}^{2+}$ can be proved by both IR and SEM. For other series of $\mathbf{C P B I}{ }_{n}$ polymers, such as $\mathbf{C P B I}_{1}, \mathbf{C} \mathbf{P B I} \mathbf{I}_{3}$, and $\mathbf{C P B I}_{4}$, their IR and SEM morphologies after the interaction with metal ions are similar (Figures S29-S31 in SM).

In addition, we further investigated the quenching process of the probe by changing the fluorescence lifetime [65]. It can be found that the presence of metal ions has no effect on the decay of the fluorescence lifetime of $\mathbf{C P B I}_{2}$ and $\mathbf{C P B I} \mathbf{I}_{4}$ when the concentration of metal ions is low (Figure S32 in SM). Therefore, it is also verified that the fluorescencequenching process of $\mathbf{C P B I}$ and $\mathbf{C} \mathbf{P B I}_{4}$ is static quenching in the low concentration range of metal ions.

Using the reported method [66-69], Gauss DFT-B3LYP/6-31G method was used to optimize the structure of $\mathbf{C P B I}_{2}, \mathbf{C P B I}_{2}-\mathrm{Cu}^{2+}$ complex, and $\mathbf{C} \mathbf{P B I} \mathbf{I}_{0}$. As shown in Figure 8, the energy of the lowest unoccupied molecular orbital (LUMO) before and after alkylation $\left(\mathrm{CPBI}_{0}\right)$ is mainly distributed on the carboxylic acid group side at the end of the polymer, and the energy is $-2.24 \mathrm{eV}$. On the contrary, the energy of the highest occupied molecular orbital (HOMO) is mainly distributed on the side containing $\mathrm{NH}_{2}$ at the end of the polymer. After the introduction of the alkyl chain, only HOMO is slightly affected, which makes the HOMO-LUMO band gap $(\Delta \mathrm{E})$ slightly larger. The structure of the complex combined with metal ions was optimized by the $\mathrm{Cu}^{2+}$ complex. It can be found that the $\Delta \mathrm{E}$ is greatly reduced when $\mathbf{C P B I}_{2}$ is complexed with $\mathrm{Cu}^{2+}$ (Figure 8). This indicates that a stable metal complex has been formed, which is further proof of coordination between metal ions and polymers [70,71]. 
LUMO
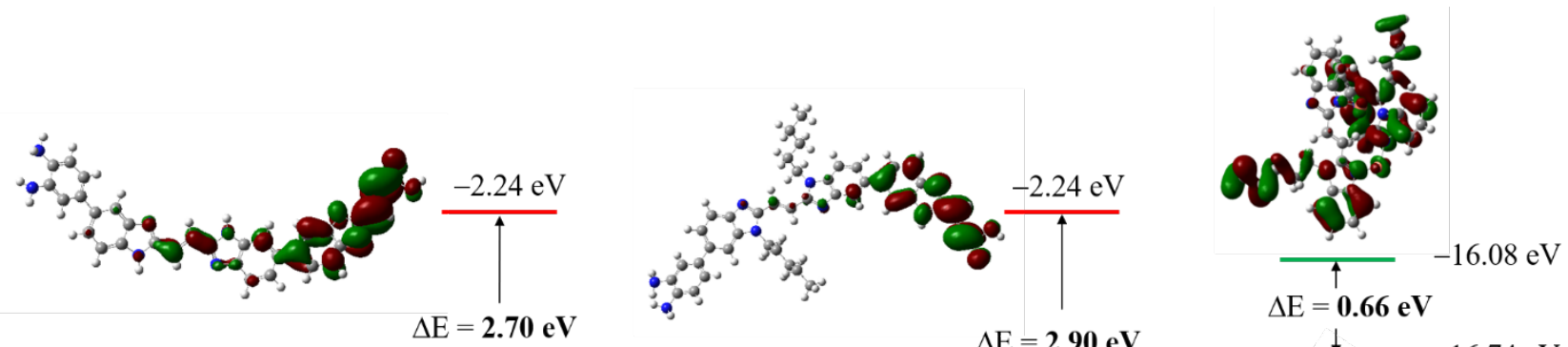

$\Delta \mathrm{E}=\mathbf{2 . 9 0} \mathbf{e V}$

$\Delta \mathrm{E}=0.66 \mathrm{eV}$

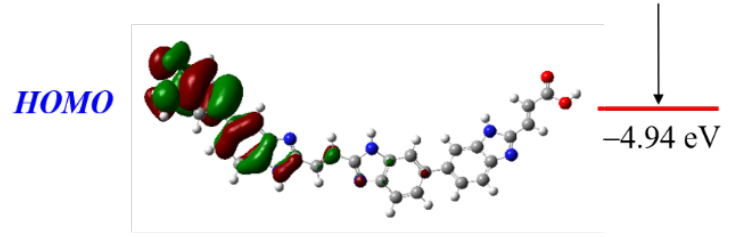

$\mathrm{CPBI}_{0}$
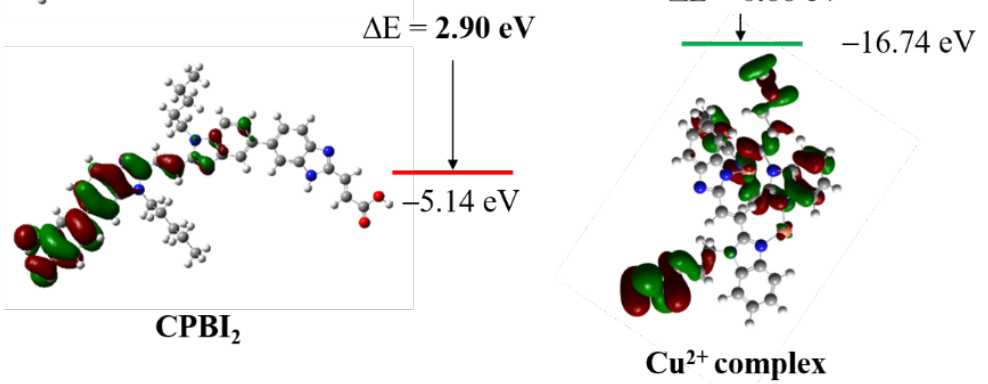

Figure 8. The optimized geometries of $\mathbf{C P B I}_{2}$, its $\mathrm{Cu}^{2+}$ complex, and $\mathbf{C P B I} \mathbf{P}_{\mathbf{0}}\left(\mathrm{B} 3 \mathrm{LYP} / 6-31 \mathrm{G}\right.$ basis set $\mathbf{C} \mathbf{P B I}_{0}, \mathbf{C P B I}_{2}$, and B3LYP/ 6-31G basis set for C, H, N; LanL2DZ for $\mathrm{Cu}^{2+}$ in complex).

\subsection{Logic Gate Construction}

The reversibility of the sensor is an important indicator of whether the sensor can be reused multiple times. $\mathbf{C P B I}_{\mathbf{2}}$ was selected for the logic gate cycle experiment (Figure 9) because of its good fluorescence-quenching effect and obvious detection phenomenon when sensing copper ions. According to the fluorescence titration experiment, when EDTA is added to $\mathbf{C P B I}_{2}-\mathrm{Cu}^{2+}$ complex, $\mathrm{Cu}^{2+}$ in the complex will bind to EDTA due to the stronger complexing ability of EDTA so that $\mathbf{C P B I}_{2}$ becomes free and the corresponding fluorescence intensity is also recovered (Figure 9b). In addition, this fluorescent "off/on" switching behavior can be observed at $365 \mathrm{~nm}$ UV lamp (Figure 9a). As a chemical sensor, CPBI 2 has shown good stability and reversibility; it is expected to be designed as a chemical sensor based on molecular logic gate [72,73].

Due to the above fluorescence quenching-restoration cycle of probe $\mathbf{C P B I}_{2}$ with $\mathrm{Cu}^{2+}$ and EDTA, a logic gate can be implemented on Boolean logic operations (Figure 9d). This is an IMPLICATION logic gate displaying memory unit with two inputs (In 1 and In 2) and one output (Figure 9e). We set $\mathrm{Cu}^{2+}$ and EDTA to inputs In 1 and In 2, respectively. Their presence and absence are denoted as 1 and 0 . The output signal is the emission intensity at $504 \mathrm{~nm}$, and the threshold is set to 1500 a.u. (Figure 9c). When the fluorescence intensity is higher than the threshold, the output signal is on (1). Additionally, when the fluorescence intensity is below the threshold, the output signal is off (0). Based on the above basic logic gate, when both $\mathrm{Cu}^{2+}$ and EDTA are present or absent, the output signal is on (1). When In 1 and In 2 are in the state $(1,0)$, the output signal is off $(0)$. When In 1 and In 2 are in the state $(0,1)$, the output signal is on (1) (Figure 9e). Therefore, the IMPLICATION logic gate can be constructed at the molecular level by monitoring the emission intensity value at 504 $\mathrm{nm}$ of the output signal through the input signal $\left(\mathrm{Cu}^{2+}\right.$ and EDTA) $[16,74-76]$.

\subsection{Visual Detection of $\mathrm{Cu}^{2+}$ in Solid State}

According to the literature method $[50,77,78]$, the thin layer chromatography (TLC) plate with $\mathbf{C P B I}_{2}$ solution adsorbed shows green fluorescence under $365 \mathrm{~nm}$ UV lamp. The fluorescence in the center of $\mathbf{C P B I}_{2}$ visible to the naked eye is rapidly quenched when $\mathrm{Cu}^{2+}$ solution is added to the TLC plate adsorbed with $\mathbf{C P B I}_{2}$, as shown in Figure 10a. Therefore, the TLC plate adsorbed with $\mathbf{C P B I}{ }_{2}$ can be used to detect $\mathrm{Cu}^{2+}$, and its visual detection of $\mathrm{Cu}^{2+}$ in solution can be achieved. 
(a)

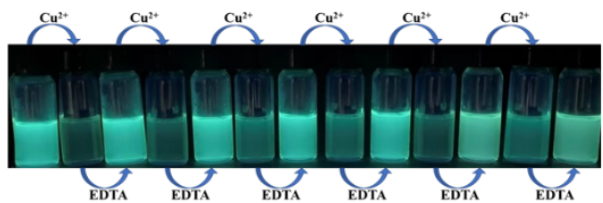

(b)

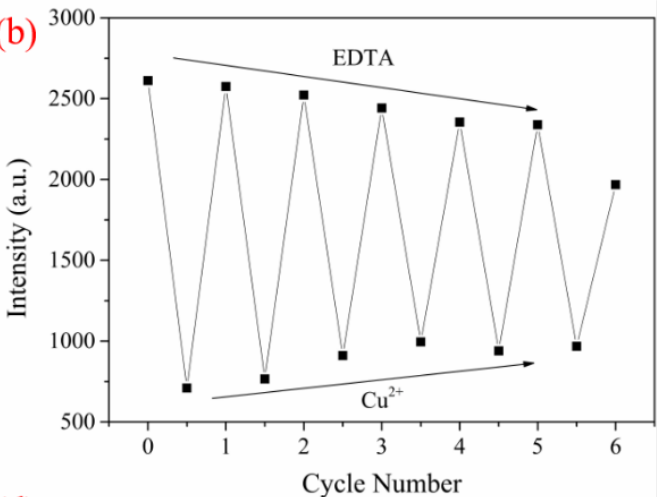

(d)

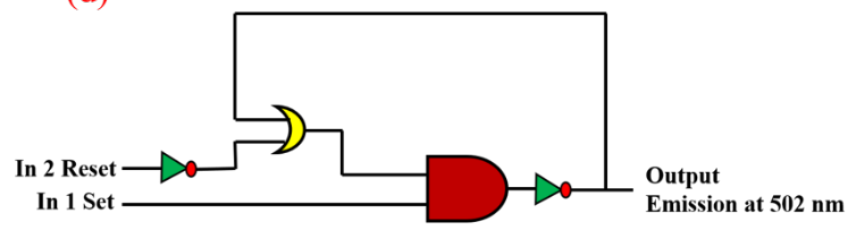

(e)

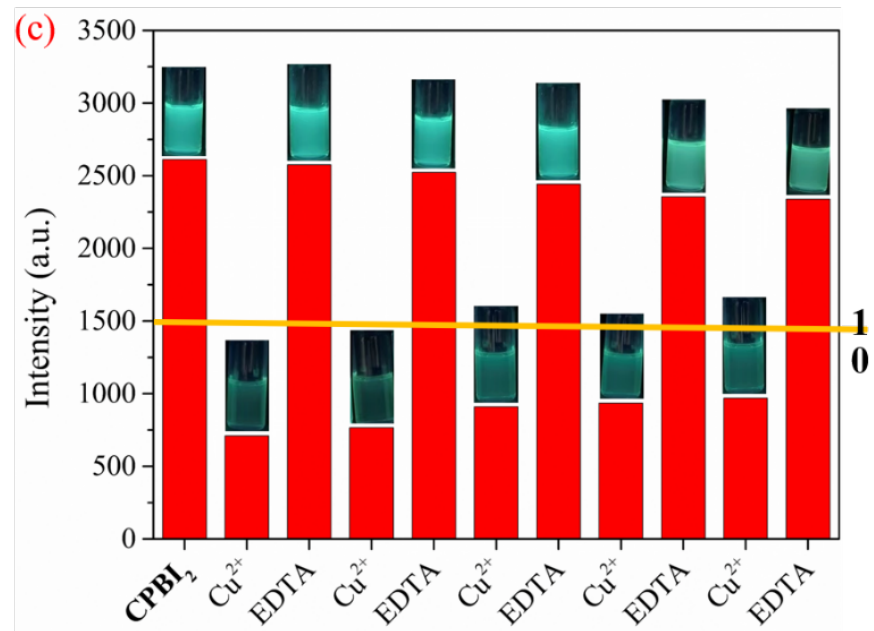

\begin{tabular}{|c|c|c|}
\hline In 1($\left(\mathrm{Cu}^{2+}\right)$ Set & In 2(EDTA) Set & $\begin{array}{c}\text { Output } \\
\boldsymbol{\lambda}_{\text {em }} \mathbf{5 0 2} \mathbf{~ n m}\end{array}$ \\
\hline 0 & 0 & 1 \\
\hline 1 & 0 & 0 \\
\hline 0 & 1 & 1 \\
\hline 1 & 1 & 1 \\
\hline
\end{tabular}

Figure 9. Fluorescence experiment of the probe $\mathbf{C P B I}_{2}$ in cyclic use: alternately adding $\mathrm{Cu}^{2+}$ and EDTA into the $\mathbf{C P B I}_{2}$ solution $\left(\lambda_{\mathrm{ex}}=375 \mathrm{~nm}\right.$ ), the color change diagram of the solution under the $365 \mathrm{~nm}$ UV lamp (a); the fluorescence intensity cycle fluorescence diagram (b); input (In $1=\mathrm{Cu}^{2+}$ and In $2=$ EDTA) histogram (c); implication logic gate (d); corresponding truth table (e).

(a)

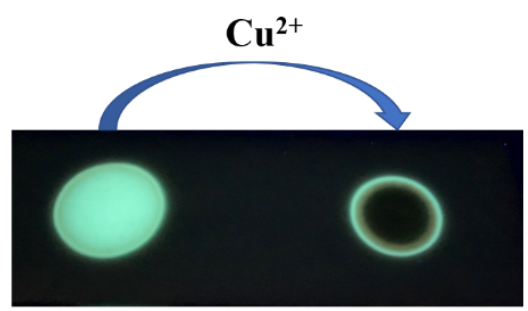

TLC plate (b)

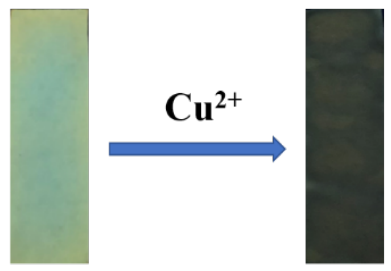

Whatman filter paper

Figure 10. Fluorescence image (under $365 \mathrm{~nm}$ UV light) of sensor $\mathbf{C P B I}_{2}$ adsorbed on a TLC plate with a spot of $\mathrm{Cu}^{2+}$ solution on sensor $\mathbf{C P B I}_{2}$ (a); fluorescence changes (under $365 \mathrm{~nm}$ UV lamp) of test strips for detecting $\mathrm{Cu}^{2+}$ in aqueous solution $(\mathbf{b})$.

In addition, according to the method reported in the literature $[47,79]$, the Whatman test paper is immersed in DMSO solution containing $\mathbf{C} \mathbf{P B I}_{2}$, and then vacuum drying makes $\mathbf{C P B I}_{2}$ test paper. The test paper shows green fluorescence under the $356 \mathrm{~nm} \mathrm{UV}$ lamp, and the fluorescence is quickly quenched when $\mathrm{Cu}^{2+}$ solution is added to the test paper (Figure 10b). Therefore, $\mathbf{C P B I}_{2}$ can be made into not only solution-coated thin layer chromatography plates but also Whatman test paper to realize solid-state visual detection of $\mathrm{Cu}^{2+}$.

\section{Conclusions}

In summary, a novel large conjugation polybenzimidazole compound $\mathbf{C} \mathbf{P B I}_{\mathbf{0}}$ was synthesized by a simple green-metal-free catalytic reaction. In order to improve its solubility and fluorescence properties, a series of different alkylated polymers $\mathbf{C} \mathbf{P B I}_{\boldsymbol{n}}$ were obtained by $N$-alkylation reaction. An alkyl chain is an electron-donor group; the difference in the 
alkylation rate means that the number of electron donors in the polymer is different, resulting in a different binding ability with electron-deficient metal ions. Therefore, although $\mathbf{C P B I}_{n}$-series polymers $\left(\mathbf{C P B I}_{1} \sim \mathrm{CPBI}_{4}\right)$ show a good recognition ability for $\mathrm{Cu}^{2+}$ and $\mathrm{Zn}^{2+}$, they have different sensitivities, indicating the regulation of the alkyl chain on the performance of a polymer fluorescent probe. In addition, $\mathbf{C P B I}_{2}$ with a nano-microsphere can be designed as an ultra-sensitive IMPLICATION logic gate at the molecular level to cyclically detect $\mathrm{Cu}^{2+}$. Furthermore, TLC plates and test papers containing $\mathbf{C P B I}_{2}$ have been developed for the solid visual detection of $\mathrm{Cu}^{2+}$ in a solution. This study provides a new idea and method for simple synthesis and fluorescence regulation of multifunctional fluorescent probes.

Supplementary Materials: The following are available online at https:/ /www.mdpi.com/article/ 10.3390/polym13183091/s1, Figure S1. ${ }^{1} \mathrm{H}$ NMR spectrum of $\mathrm{CPBI}_{0}$; Figure S2. ${ }^{1} \mathrm{H}$ NMR spectrum of $\mathrm{CPBI}_{1}$; Figure S3. ${ }^{1} \mathrm{H}$ NMR spectrum of $\mathrm{CPBI}_{2}$; Figure $\mathrm{S} 4 .{ }^{1} \mathrm{H}$ NMR spectrum of $\mathrm{CPBI}_{3}$; Figure $55 .{ }^{1} \mathrm{H}$ NMR spectrum of $\mathrm{CPBI}_{4}$; Figure $\mathrm{S6} .{ }^{1} \mathrm{H}$ NMR spectrum of $\mathrm{CPBI}_{5}$; Figure S7. The changes of ${ }^{1} \mathrm{H}$ NMR spectra of CPBIs with different molar feed ratios $\left[n\left(\mathrm{C}_{5} \mathrm{H}_{11} \mathrm{Br}\right) / n\left(\mathrm{CPBI}_{0}\right)\right]$; Figure S8. The FT-IR spectra of CPBIs with different molar feed ratios $\left[n\left(\mathrm{C}_{5} \mathrm{H}_{11} \mathrm{Br}\right) / n\left(\mathrm{CPBI}_{0}\right)\right]$; Figure S9. The full XPS spectra of $\mathrm{CPBI}_{2}$ (a) and its $\mathrm{C} 1 \mathrm{~s}$ (b), N1s (c) peaks; Figure S10. The XRD analysis of CPBIn with different molar feed ratios $\left[n\left(\mathrm{C}_{5} \mathrm{H}_{11} \mathrm{Br}\right) / n\left(\mathrm{CPBI}_{0}\right)\right]$; Figure $\mathrm{S} 11$. TG analysis of CPBIs with different molar feed ratios $\left[n\left(\mathrm{C}_{5} \mathrm{H}_{11} \mathrm{Br}\right) / n\left(\mathrm{CPBI}_{0}\right)\right]$; Figure S12. SEM analysis of $\mathrm{CPBI}_{n}$ with different molar feed ratios; Figure S13. Fluorescence emission spectra in different polar solvents $(\lambda e x=375 \mathrm{~nm})$ of $\mathrm{CPBI}_{1}(\mathrm{a})$, $\mathrm{CPBI}_{2}$ (b), $\mathrm{CPBI}_{3}$ (c) and $\mathrm{CPBI}_{4}$ (d); Figure S14. Fluorescence emission spectra in DMSO solutions $(1 \mathrm{mg} / 15 \mathrm{~mL})$ with different water content as DMSO $/ \mathrm{H}_{2} \mathrm{O}(v / v)$ of $\mathrm{CPBI}_{1}(\mathrm{a}), \mathrm{CPBI}_{2}$ (b), $\mathrm{CPBI}_{3}$ (c) and $\mathrm{CPBI}_{4}(\mathrm{~d}), \lambda e x=375 \mathrm{~nm}$; Figure S15. Fluorescence emission spectra of sensor $\mathrm{CPBI}_{2}$ solution $\left(1 \mathrm{mg} / 15 \mathrm{~mL}\right.$ in DMSO$\left./ \mathrm{H}_{2} \mathrm{O}, v / v, 9 / 1\right)$ with $\mathrm{Zn}^{2+}(100 \mu \mathrm{M})$ and other metal ions $(100 \mu \mathrm{M})(\mathrm{a})$ and comparison of fluorescence quenching rate (b), fluorescence emission spectra of $\mathrm{Cu}^{2+}(100 \mu \mathrm{M})$ and other metal ions (c) and comparison of fluorescence quenching rate (d), $\lambda e x=375 \mathrm{~nm}$; Figure S16. The fluorescence selectivity study of different metal ions $(100 \mu \mathrm{M})$ in $\mathrm{CPBI}_{1}\left(1 \mathrm{mg} / 15 \mathrm{~mL}\right.$ in DMSO $/ \mathrm{H}_{2} \mathrm{O}$, $v / v, 9 / 1)$ solution (a), the influence of adding different metal ions $(100 \mu \mathrm{M})$ on $\mathrm{CPBI}_{1}$ fluorescence intensity at $500 \mathrm{~nm}(\mathrm{~b}), \lambda e x=375 \mathrm{~nm}$; Figure S17. Fluorescence emission spectra of sensor CPBI1 solution $\left(1 \mathrm{mg} / 15 \mathrm{~mL}\right.$ in $\left.\mathrm{DMSO} / \mathrm{H}_{2} \mathrm{O}, v / v, 9 / 1\right)$ with $\mathrm{Cu}^{2+}(100 \mu \mathrm{M})$ and other metal ions $(100 \mu \mathrm{M})$ (the upper), fluorescence emission spectra of $\mathrm{Zn}^{2+}(100 \mu \mathrm{M})$ and other metal ions $(100 \mu \mathrm{M})$ (the lower), $\lambda e x=375 \mathrm{~nm}$; Figure S18. Fluorescence emission spectra of CPBI1 $\left(1 \mathrm{mg} / 15 \mathrm{~mL}\right.$ in DMSO $/ \mathrm{H}_{2} \mathrm{O}$, $v / v, 9 / 1)$ solution with different concentrations of $\mathrm{Cu}^{2+}$ and the linear relationship between $\mathrm{CPBI}_{1}$ and low concentrations of $\mathrm{Cu}^{2+}, \lambda \mathrm{ex}=375 \mathrm{~nm}$; Figure S19. Fluorescence emission spectra of $\mathrm{CPBI}_{1}$ $\left(1 \mathrm{mg} / 15 \mathrm{~mL}\right.$ in $\left.\mathrm{DMSO} / \mathrm{H}_{2} \mathrm{O}, v / v, 9 / 1\right)$ solution with different concentrations of $\mathrm{Zn}^{2+}$ and the linear relationship between $\mathrm{CPBI}_{1}$ and low concentrations of $\mathrm{Zn}^{2+}, \lambda \mathrm{ex}=375 \mathrm{~nm}$; Figure S20. The fluorescence selectivity study of different metal ions $(100 \mu \mathrm{M})$ in $\mathrm{CPBI}_{3}\left(1 \mathrm{mg} / 15 \mathrm{~mL}\right.$ in DMSO $/ \mathrm{H}_{2} \mathrm{O}$, $v / v, 9 / 1)$ solution (a), the influence of adding different metal ions $(100 \mu \mathrm{M})$ on $\mathrm{CPBI}_{3}$ fluorescence intensity at $510 \mathrm{~nm}(\mathrm{~b}), \lambda \mathrm{ex}=375 \mathrm{~nm}$; Figure S21. Fluorescence emission spectra of sensor $\mathrm{CPBI}_{3}$ solution $\left(1 \mathrm{mg} / 15 \mathrm{~mL}\right.$ in $\left.\mathrm{DMSO} / \mathrm{H}_{2} \mathrm{O}, v / v, 9 / 1\right)$ with $\mathrm{Cu}^{2+}(100 \mu \mathrm{M})$ and other metal ions $(100 \mu \mathrm{M})$ (the upper), fluorescence emission spectra of $\mathrm{Zn}^{2+}(100 \mu \mathrm{M})$ and other metal ions $(100 \mu \mathrm{M})$ (the lower), $\lambda$ ex $=375 \mathrm{~nm}$; Figure S22. Fluorescence emission spectra of $\mathrm{CPBI}_{3}\left(1 \mathrm{mg} / 15 \mathrm{~mL}\right.$ in DMSO $/ \mathrm{H}_{2} \mathrm{O}$, $v / v, 9 / 1)$ solution with different concentrations of $\mathrm{Cu}^{2+}$ and the linear relationship between $\mathrm{CPBI}_{3}$ and low concentrations of $\mathrm{Cu}^{2+}, \lambda \mathrm{ex}=375 \mathrm{~nm}$; Figure S23. Fluorescence emission spectra of $\mathrm{CPBI}_{3}$ $\left(1 \mathrm{mg} / 15 \mathrm{~mL}\right.$ in DMSO$\left./ \mathrm{H}_{2} \mathrm{O}, v / v, 9 / 1\right)$ solution with different concentrations of $\mathrm{Zn}^{2+}$ and the linear relationship between $\mathrm{CPBI}_{3}$ and low concentrations of $\mathrm{Zn}^{2+}, \lambda \mathrm{ex}=375 \mathrm{~nm}$; Figure S24. The fluorescence selectivity study of different metal ions $(100 \mu \mathrm{M})$ in CPBI4 $\left(1 \mathrm{mg} / 15 \mathrm{~mL}\right.$ in DMSO $/ \mathrm{H}_{2} \mathrm{O}$, $v / v, 9 / 1)$ solution, $\lambda \mathrm{ex}=375 \mathrm{~nm}(\mathrm{a})$, the influence of adding different metal ions $(100 \mu \mathrm{M})$ on CPBI4 fluorescence intensity at $510 \mathrm{~nm}$ (b) and the color change of the solution (c); Figure S25. Fluorescence emission spectra of sensor $\mathrm{CPBI}_{4}$ solution $\left(1 \mathrm{mg} / 15 \mathrm{~mL}\right.$ in DMSO $\left./ \mathrm{H}_{2} \mathrm{O}, v / v, 9 / 1\right)$ with $\mathrm{Zn}^{2+}(100 \mu \mathrm{M})$ and other metal ions $(100 \mu \mathrm{M})(\mathrm{a})$ and comparison of fluorescence quenching rate (b), fluorescence emission spectra of $\mathrm{Cu}^{2+}(100 \mu \mathrm{M})$ and other metal ions $(100 \mu \mathrm{M})(\mathrm{c})$ and comparison of fluorescence quenching rate (d), $\lambda$ ex $=375 \mathrm{~nm}$; Figure S26. Fluorescence emission spectra of CPBI4 $(1 \mathrm{mg} / 15 \mathrm{~mL}$ in $\left.\mathrm{DMSO} / \mathrm{H}_{2} \mathrm{O}, v / v, 9 / 1\right)$ solution with different concentrations of $\mathrm{Cu}^{2+}$ and the linear relationship between CPBI4 and low concentrations of $\mathrm{Cu}^{2+}, \lambda \mathrm{ex}=375 \mathrm{~nm}$; Figure S27. Fluorescence emission 
spectra of $\mathrm{CPBI}_{4}\left(1 \mathrm{mg} / 15 \mathrm{~mL}\right.$ in $\left.\mathrm{DMSO} / \mathrm{H}_{2} \mathrm{O}, v / v, 9 / 1\right)$ solution with different concentrations of $\mathrm{Zn}^{2+}$ and the linear relationship between $\mathrm{CPBI}_{4}$ and low concentrations of $\mathrm{Zn}^{2+}, \lambda \mathrm{ex}=375 \mathrm{~nm}$; Figure S28. Stern-Volmer diagram of the interaction of sensors CPBI4 with $\mathrm{Cu}^{2+}$ (a) and $\mathrm{Zn}^{2+}$ (b) (the illustration shows the Stern-Volmer linear diagram at low concentrations); Figure S29. FT-IR spectra (a), SEM images of $\mathrm{CPBI}_{1}$ before and after the addition of $\mathrm{Cu}^{2+}$ or $\mathrm{Zn}^{2+}\left(\mathrm{b}: \mathrm{CPBI}_{1}+\mathrm{Zn}^{2+}\right.$; c: $\left.\mathrm{CPBI}_{1}+\mathrm{Cu}^{2+} ; \mathrm{d}: \mathrm{CPBI}_{1}\right)$; Figure S30. FT-IR spectra (a), SEM images of $\mathrm{CPBI}_{3}$ before and after the addition of $\mathrm{Cu} 2+$ or $\mathrm{Zn}^{2+}$ (b: $\mathrm{CPBI}_{3}+\mathrm{Zn}^{2+} ; \mathrm{c}: \mathrm{CPBI}_{3}+\mathrm{Cu}^{2+} ; \mathrm{d}: \mathrm{CPBI}_{3}$ ); Figure S31. FT-IR spectra (a), SEM images of $\mathrm{CPBI}_{4}$ before and after the addition of $\mathrm{Cu}^{2+}$ or $\mathrm{Zn}^{2+}\left(\mathrm{b}: \mathrm{CPBI}_{4}+\mathrm{Zn}^{2+} ; \mathrm{c}: \mathrm{CPBI}_{4}{ }^{+}\right.$ $\mathrm{Cu}^{2+}$; d: $\mathrm{CPBI}_{4}$ ); +; Figure S32. Time-correlated single photon counting (TCSPC) plot for $\mathrm{CPBI}_{2}$ (left) and $\mathrm{CPBI}_{4}$ (right) interacted with $\mathrm{Cu}^{2+}$ and $\mathrm{Zn}^{2+}\left(\lambda \mathrm{ex}=375 \mathrm{~nm}, \lambda \mathrm{em}=504 \mathrm{~nm}\right.$ for $\mathrm{CPBI}_{2}$ and $\lambda \mathrm{em}$ $=510 \mathrm{~nm}$ for $\mathrm{CPBI}_{4}$, respectively). Table S1. The effects of different feed ratios on yield, color and actual alkylation rate of CPBIn; Table S2. The thermal decomposition temperatures of CPBIs with different feed ratios; Table S3. Photophysical properties of CPBIn with different feed ratios. Table S4. Comparison of LOD when the sensor $\mathrm{CPBI}_{n}$ detects $\mathrm{Cu}^{2+}$ and $\mathrm{Zn}^{2+}$; Table S5. The comparison of probe CPBIn with the reported $\mathrm{Cu}^{2+}$ probes in solution; Table S6. The comparison of probe $\mathrm{CPBI}_{n}$ with the reported $\mathrm{Zn}^{2+}$ probes in solution.

Author Contributions: Conceptualization, X.-Y.C. and Z.-Y.W.; methodology, X.-Y.C. and C.-M.P.; software, Y.X.; validation, S.-H.L., W.-Q.X. and Z.-Y.W.; formal analysis, Y.X.; investigation, J.-P.H.; data curation, C.-M.P.; writing-original draft preparation, X.-Y.C.; writing-review and editing, Z.-Y.W., X.-Y.C., C.-M.P., Y.X., S.-H.L., W.-Q.X. and J.-P.H.; visualization, S.-H.L.; supervision, Z.-Y.W.; project administration, Z.-Y.W.; funding acquisition, Z.-Y.W. All authors have read and agreed to the published version of the manuscript.

Funding: Financial support from the National Natural Science Foundation of China (20772035), Guangdong Basic and Applied Basic Research Foundation (No. 2021A1515012342), and Guangdong Provincial Science and Technology Project (No. 2017A010103016) is greatly appreciated.

Institutional Review Board Statement: Not applicable.

Informed Consent Statement: Not applicable.

Data Availability Statement: Data can be made available from the authors upon reasonable request.

Conflicts of Interest: The authors declare no conflict of interest.

\section{References}

1. Wang, K.-N.; Liu, L.-Y.; Mao, D.; Xu, S.D.; Tan, C.-P.; Cao, Q.; Mao, Z.-W.; Liu, B. A Polarity-Sensitive Ratiometric Fluorescence Probe for Monitoring Changes in Lipid Droplets and Nucleus during Ferroptosis. Angew. Chem. Int. Ed. 2021, 60, 15095-15100. [CrossRef]

2. Wan, W.; Huang, Y.; Xia, Q.; Bai, Y.; Chen, Y.; Jin, W.; Wang, M.; Shen, D.; Lyu, H.; Tang, Y.; et al. Covalent Probes for Aggregated Protein Imaging via Michael Addition. Angew. Chem. Int. Ed. 2021, 60, 11335-11343. [CrossRef] [PubMed]

3. Maimaitiyiming, X.; Shi, C. Poly(1,4-diethynylphenylene-4,6-pyrimidine)s for fluorescence detection of mercury(II) ion. Mater. Chem. Phys. 2021, 257, 123783. [CrossRef]

4. Kim, J.; Lee, J.; Lee, T.S. Size-dependent fluorescence of conjugated polymer dots and correlation with the fluorescence in solution and in the solid phase of the polymer. Nanoscale 2020, 12, 2492-2497. [CrossRef] [PubMed]

5. Wang, S.; Ren, W.X.; Hou, J.-T.; Won, M.; An, J.S.; Chen, X.; Shu, J.; Kim, J.S. Fluorescence imaging of pathophysiological microenvironments. Chem. Soc. Rev. 2021, 50, 8887-8902. [CrossRef] [PubMed]

6. Zhang, D.; Wang, Z.; Yang, J.; Yi, L.; Liao, L.; Xiao, X. Development of a method for the detection of $\mathrm{Cu}^{2+}$ in the envi-ronment and live cells using a synthesized spider web-like fluorescent probe. Biosens. Bioelectron. 2021, 182, 113174. [CrossRef] [PubMed]

7. Kometani, A.; Inagaki, Y.; Mutoh, K.; Abe, J. Red or near-infrared light operating negative photochromism of a binaph-thylbridged imidazole dimer. J. Am. Chem. Soc. 2020, 142, 7995-8005. [CrossRef] [PubMed]

8. Zhao, X.; Fan, Z.; Qiao, Y.; Chen, Y.; Wang, S.; Yue, X.; Shen, T.; Liu, W.; Yang, J.; Gao, H.; et al. AIEgens Conjugation Improves the Photothermal Efficacy and Near-Infrared Imaging of Heptamethine Cyanine IR-780. ACS Appl. Mater. Interfaces 2020, 12, 16114-16124. [CrossRef]

9. Mehta, P.K.; Neupane, L.N.; Park, S.-H.; Lee, K.-H. Ratiometric fluorescent detection of silver nanoparticles in aqueous samples using peptide-based fluorogenic probes with aggregation-induced emission characteristics. J. Hazard. Mater. 2021, $411,125041$. [CrossRef]

10. Wang, M.; Zhang, R.; Dehaen, W.; Fang, Y.; Qian, S.; Ren, Y.; Cheng, F.; Guo, Y.; Guo, C.; Li, Y.; et al. Specific recognition, intracellular assay and detoxification of fluorescent curcumin derivative for copper ions. J. Hazard. Mater. 2021, 420, 126490. [CrossRef] 
11. Portelinha, J.; Duay, S.S.; Yu, S.I.; Heilemann, K.; Libardo, M.D.J.; Juliano, S.A.; Klassen, J.L.; Angeles-Boza, A.M. Antimicrobial Peptides and Copper(II) Ions: Novel Therapeutic Opportunities. Chem. Rev. 2021, 121, 2648-2712. [CrossRef]

12. Arvas, B.; Ucar, B.; Acar, T.; Arvas, M.B.; Sahin, Y.; Aydogan, F.; Yolacan, C. A new coumarin based Schiff base fluorescence probe for zinc ion. Tetrahedron 2021, 88, 132127. [CrossRef]

13. Dai, C.; Qian, H.-L.; Yan, X.-P. Facile room temperature synthesis of ultra-small sized porous organic cages for fluorescent sensing of copper ion in aqueous solution. J. Hazard. Mater. 2021, 416, 125860. [CrossRef]

14. Wang, X.; Shen, C.; Zhou, C.; Bu, Y.; Yan, X. Methods, principles and applications of optical detection of metal ions. Chem. Eng. J. 2021, 417, 129125. [CrossRef]

15. Chakraborty, G.; Katiyar, V.; Pugazhenthi, G. Improvisation of polylactic acid (PLA)/exfoliated graphene (GR) nanocomposite for detection of metal ions $\left(\mathrm{Cu}^{2+}\right)$. Compos. Sci. Technol. 2021, 213, 108877. [CrossRef]

16. Zeng, S.; Li, S.-J.; Sun, X.-J.; Liu, T.-T.; Xing, Z.-Y. A dual-functional chemosensor for fluorescent on-off and ratiometric detection of $\mathrm{Cu}^{2+}$ and $\mathrm{Hg}^{2+}$ and its application in cell imaging. Dye. Pigment. 2019, 170, 107642. [CrossRef]

17. Pang, C.-M.; Chen, S.-H.; Cao, X.-Y.; Zhang, J.-R.; Xiao, Y.; Li, X.-D.; Luo, S.-H.; Wang, Z.-Y. A multifunctional probe based on the conjugate of four fused $N$-heterocycles: Detecting picric acid, $\mathrm{Cu}^{2+}$ and $\mathrm{Al}^{3+}$ in ethanol solution system. J. Photochem. Photobiol. A Chem. 2020, 403, 112835. [CrossRef]

18. Pavadai, R.; Amalraj, A.; Subramanian, S.; Perumal, P. High catalytic activity of fluorophore-labeled Y-shaped DNAzyme/3D MOF-MoS ${ }_{2} \mathrm{NBs}$ as a versatile biosensing platform for the simultaneous detection of $\mathrm{Hg}^{2+}, \mathrm{Ni}^{2+}$, and Ag+ ions. ACS Appl. Mater. Interfaces 2021, 13, 31710-31724. [CrossRef] [PubMed]

19. Liu, J.; Liu, Z.; Wang, W.; Tian, Y. Real-time Tracking and Sensing of $\mathrm{Cu}^{+}$and $\mathrm{Cu}^{2+}$ with a Single SERS Probe in the Live Brain: Toward Understanding Why Copper Ions Were Increased upon Ischemia. Angew. Chem. Int. Ed. 2021. [CrossRef]

20. Pang, C.-M.; Luo, S.-H.; Jiang, K.; Wang, B.-W.; Chen, S.-H.; Wang, N.; Wang, Z.-Y. A dual-channel sensor containing multiple nitrogen heterocycles for the selective detection of $\mathrm{Cu}^{2+}, \mathrm{Hg}^{2+}$ and $\mathrm{Zn}^{2+}$ in same solvent system by different mechanism. Dye. Pigment. 2019, 170, 107651. [CrossRef]

21. Desai, M.L.; Basu, H.; Saha, S.; Singhal, R.K.; Kailasa, S.K. One pot synthesis of fluorescent gold nanoclusters from Curcuma longa extract for independent detection of $\mathrm{Cd}^{2+}, \mathrm{Zn}^{2+}$ and $\mathrm{Cu}^{2+}$ ions with high sensitivity. J. Mol. Liq. 2020, 304, 112697. [CrossRef]

22. Xiao, Y.; Ma, J.; Li, D.; Liu, L.; Wang, H. Preparation $4^{\prime}$-Quinolin-2-yl- $\left[2,2^{\prime} ; 6^{\prime}, 2^{\prime \prime}\right]$ terpyridine as a ratiometric fluorescent probe for cadmium ions and zinc ions in aqueous. J. Photochem. Photobiol. A 2020, 399, 112613. [CrossRef]

23. Shellaiah, M.; Thirumalaivasan, N.; Aazaad, B.; Awasthi, K.; Sun, K.W.; Wu, S.-P.; Lin, M.-C.; Ohta, N. Novel rhodamine probe for colorimetric and fluorescent detection of $\mathrm{Fe}^{3+}$ ions in aqueous media with cellular imaging. Spectrochim. Acta Part A Mol. Biomol. Spectrosc. 2020, 242, 118757. [CrossRef]

24. Liu, A.; Ji, R.; Shen, S.; Cao, X.; Ge, Y. A ratiometric fluorescent probe for sensing sulfite based on a pyrido[1,2-a]benzimidazole fluorophore. New J. Chem. 2017, 41, 10096-10100. [CrossRef]

25. Xu, P.; Liu, X.; Liu, L.; Zhu, W.; Li, C.; Fang, M. Carbazole-based colorimetric and fluorescent probe for Cu 2+ and its utility in bio-imaging and real water samples. J. Chin. Chem. Soc. 2020, 68, 106-113. [CrossRef]

26. Yu, Y.; Xu, W.; Wang, T.; Fu, Y.; Cao, H.; He, Q.; Cheng, J. More Interaction Sites and Enhanced Fluorescence for Highly Sensitive Fluorescence Detection of Methamphetamine Vapor via Sidechain Terminal Functionalization of Conjugated Polymers. ChemistrySelect 2020, 5, 8328-8337. [CrossRef]

27. Saes, B.W.H.; Lutz, M.; Wienk, M.M.; Meskers, S.C.J.; Janssen, R.A.J. Tuning the Optical Characteristics of Diketopyrrolopyrrole Molecules in the Solid State by Alkyl Side Chains. J. Phys. Chem. C 2020, 124, 25229-25238. [CrossRef] [PubMed]

28. Qi, J.; Duan, X.; Cai, Y.; Jia, S.; Chen, C.; Zhao, Z.; Li, Y.; Peng, H.-Q.; Kwok, R.T.K.; Lam, J.W.Y.; et al. Simultaneously boosting the conjugation, brightness and solubility of organic fluorophores by using AIEgens. Chem. Sci. 2020, 11, 8438-8447. [CrossRef] [PubMed]

29. Chochos, C.L.; Choulis, S.A. How the structural deviations on the backbone of conjugated polymers influence their optoelec-tronic properties and photovoltaic performance. Prog. Polym. Sci. 2011, 36, 1326-1414. [CrossRef]

30. Yang, Q.; Hu, Z.; Zhu, S.; Ma, R.; Ma, H.; Ma, Z.; Wan, H.; Zhu, T.; Jiang, Z.; Liu, W.; et al. Donor Engineering for NIR-II Molecular Fluorophores with Enhanced Fluorescent Performance. J. Am. Chem. Soc. 2018, 140, 1715-1724. [CrossRef]

31. Huang, Y.; You, X.; Wang, L.; Zhang, G.; Gui, S.; Jin, Y.; Zhao, R.; Zhang, D. Pyridinium-substituted tetra-phenylethylenes functionalized with alkyl chains as autophagy modulators for cancer therapy. Angew. Chem. Int. Ed. 2020, 59, 10042-10051. [CrossRef]

32. Jia, P.; Xu, L.; Hu, Y.; Li, W.; Wang, X.; Ling, Q.; Shi, X.; Yin, G.; Li, X.; Sun, H.; et al. Orthogonal self-assembly of a two-step fluorescence-resonance energy transfer system with improved photosensitization effi-ciency and photooxidation activity. J. Am. Chem. Soc. 2021, 143, 399-408. [CrossRef] [PubMed]

33. Huang, F.; Pingitore, A.T.; Benicewicz, B.C. Electrochemical Hydrogen Separation from Reformate Using High-Temperature Polybenzimidazole (PBI) Membranes: The Role of Chemistry. ACS Sustain. Chem. Eng. 2020, 8, 6234-6242. [CrossRef]

34. Konovalova, A.; Stock, D.; Schröder, S.; Park, H.S.; Jang, J.H.; Kim, H.-J.; Han, J.; Schröder, D.; Henkensmeier, D. Partially methylated polybenzimidazoles as coating for alkaline zinc anodes. J. Membr. Sci. 2020, 610, 118254. [CrossRef]

35. Aili, D.; Yang, J.S.; Jankova, K.; Henkensmeier, D.; Li, Q. From polybenzimidazoles to polybenzimidazoliums and polybenzimidazolides. J. Mater. Chem. A 2020, 8, 12854-12886. [CrossRef] 
36. Hussaini, S.Y.; Haque, R.A.; Fatima, T.; Agha, T.M.; Majid, A.M.S.A.; Abdallah, H.H.; Razali, M.R. Nitrile functionalized silver(I) N-heterocyclic carbene complexes: DFT calculations and antitumor studies. Transit. Met. Chem. 2018, 43, 301-312. [CrossRef]

37. Shannon, M.S.; Hindman, M.S.; Danielsen, S.P.O.; Tedstone, J.M.; Gilmore, R.D.; Bara, J.E. Properties of alkylbenzimidazoles for $\mathrm{CO}_{2}$ and $\mathrm{SO}_{2}$ capture and comparisons to ionic liquids. Sci. China Chem. 2012, 55, 1638-1647. [CrossRef]

38. Shahini, C.; Achar, G.; Budagumpi, S.; Tacke, M.; Patil, S.A. Synthesis, structural investigation and antibacterial studies of non-symmetrically p-nitrobenzyl substituted benzimidazole $\mathrm{N}$-heterocyclic carbene-silver(I) complexes. Inorg. Chim. Acta 2017, 466, 432-441. [CrossRef]

39. Du, Y.; Song, Y.; Hao, J.; Cai, K.; Liu, N.; Yang, L.; Wang, L. Ratiometric fluorescence detection of O ${ }^{-2}$ (center dot-) based on dual-emission Schiff base polymer/rhodamine-B nanocomposites. Talanta 2019, 198, 316-322. [CrossRef]

40. Dong, S.; Wang, S.; Wang, X.; Zhai, L. Superparamagnetic nanocomposite $\mathrm{Fe}_{3} \mathrm{O}_{4} @ \mathrm{SiO}_{2}-\mathrm{NH}_{2} / \mathrm{CQDs}$ as fluorescent probe for copper (II) detection. Mater. Lett. 2020, 278, 128404. [CrossRef]

41. Guo, X.; Huang, J.; Wang, M.; Wang, L. A dual-emission water-soluble g- $\mathrm{C}_{3} \mathrm{~N}_{4} @ \mathrm{AuNCs}$-based fluorescent probe for label-free and sensitive analysis of trace amounts of ferrous (II) and copper (II) ions. Sens. Actuators B 2020, 309, 127766. [CrossRef]

42. He, Y.; Li, N.; Li, W.; Zhang, X.; Zhang, X.; Liu, Z.; Liu, Q. 5,10,15,20-tetrakis (4-carboxylphenyl) porphyrin func-tionalized $\mathrm{NiCo}_{2} \mathrm{~S}_{4}$ yolk-shell nanospheres: Excellent peroxidase-like activity, catalytic mechanism and fast cascade colorimetric biosensor for cholesterol. Sens. Actuators B 2021, 326, 128850. [CrossRef]

43. Giri, D.; Bankura, A.; Patra, S.K. Poly(benzodithieno-imidazole-alt-carbazole) based $\pi$-conjugated copolymers: Highly selective and sensitive turn-off fluorescent probes for $\mathrm{Hg}^{2+}$. Polymer 2018, 158, 338-353. [CrossRef]

44. Li, W.; Zhang, X.; Hu, X.; Shi, Y.; Li, Z.; Huang, X.; Zhang, W.; Zhang, D.; Zou, X.; Shi, J. A smartphone-integrated ratiometric fluorescence sensor for visual detection of cadmium ions. J. Hazard. Mater. 2021, 408, 124872. [CrossRef] [PubMed]

45. Ding, N.; Xu, H.; Zong, S.; Gong, Y.; Hao, Y.; Tang, X.; Li, Z. Detection of Tyrosinase in Real Food Samples and Living Cells by a Novel Near-Infrared Fluorescence Probe. J. Agric. Food Chem. 2021, 69, 1994-2000. [CrossRef] [PubMed]

46. Liu, T.; Pan, X.; Meng, X.; Liu, Y.; Wei, D.; Ma, W.; Huo, L.; Sun, X.; Lee, T.; Huang, M.; et al. Alkyl Side-Chain Engineering in Wide-Bandgap Copolymers Leading to Power Conversion Efficiencies over 10\%. Adv. Mater. 2017, 29. [CrossRef] [PubMed]

47. Kaewnok, N.; Sirirak, J.; Jungsuttiwong, S.; Wongnongwa, Y.; Kamkaew, A.; Petdum, A.; Panchan, W.; Sahasithiwat, S.; Sooksimuang, T.; Charoenpanich, A.; et al. Detection of hazardous mercury ion using [5] helicene-based fluo-rescence probe with "turn-ON" sensing response for practical applications. J. Hazard. Mater. 2021, 418, 126242. [CrossRef]

48. Xia, Q.; Feng, S.; Hong, J.; Feng, G. One probe for multiple targets: A NIR fluorescent rhodamine-based probe for ONOO ${ }^{-}$and lysosomal pH detection in live cells. Sens. Actuators B Chem. 2021, 337, 129732. [CrossRef]

49. Yang, S.; Zhou, F.; Yao, X.; Liu, W.; Zhu, W.; Qian, X.; Liu, Y. A novel near-infrared fluorescent probe to in vivo evaluate the release efficiency of $\mathrm{H}_{2} \mathrm{~S}$ prodrug. Sens. Actuators B Chem. 2021, 339, 129881. [CrossRef]

50. Jung, J.M.; Lee, S.Y.; Nam, E.; Lim, M.H.; Kim, C. A highly selective turn-on chemosensor for $\mathrm{Zn}^{2+}$ in aqueous media and living cells. Sens. Actuators B Chem. 2017, 244, 1045-1053. [CrossRef]

51. Wang, Y.; Lao, S.; Ding, W.; Zhang, Z.; Liu, S. A novel ratiometric fluorescent probe for detection of iron ions and zinc ions based on dual-emission carbon dots. Sens. Actuators B Chem. 2019, 284, 186-192. [CrossRef]

52. Du, T.; Wang, J.; Zhang, T.; Zhang, L.; Yang, C.; Yue, T.; Sun, J.; Li, T.; Zhou, M.; Wang, J. An Integrating Platform of Ratiometric Fluorescent Adsorbent for Unconventional Real-Time Removing and Monitoring of Copper Ions. ACS Appl. Mater. Interfaces 2020, 12, 13189-13199. [CrossRef]

53. Sonkar, A.K.; Rai, A.; Tripathi, K.; Yadav, R.; Shukla, M.; Chauhan, B.S.; Srikrishna, S.; Mishra, L. A dual optical probe with larger stokes shift for simultaneous detection of $\mathrm{Cu}^{2+}$ and $\mathrm{Zn}^{2+}$ ions and aggregation induced enhanced emission empowering selective detection of $\mathrm{Cu}^{2+}$ ions. Sens. Actuators B Chem. 2021, 327, 129011. [CrossRef]

54. Aysha, T.S.; El-Sedik, M.S.; Mohamed, M.B.I.; Gaballah, S.T.; Kamel, M.M. Dual functional colorimetric and turn-off fluores-cence probe based on pyrrolinone ester hydrazone dye derivative for $\mathrm{Cu}^{2+}$ monitoring and $\mathrm{pH}$ change. Dyes Pigment. 2019, 170, 107549. [CrossRef]

55. Erdemir, S.; Malkondu, S. Dual-channel responsive fluorescent sensor for the logic-controlled detection and bioimaging of $\mathrm{Zn}^{2+}$ and $\mathrm{Hg}^{2+}$. J. Mol. Liq. 2021, 326, 115279. [CrossRef]

56. Xie, H.-F.; Yu, C.-J.; Huang, Y.-L.; Xu, H.; Zhang, Q.-L.; Sun, X.-H.; Feng, X.; Redshaw, C. A turn-off fluorescent probe for the detection of $\mathrm{Cu}^{2+}$ based on a tetraphenylethylene-functionalized salicylaldehyde Schiff-base. Mater. Chem. Front. 2020, 4, 1500-1506. [CrossRef]

57. Liu, Y.-J.; Tian, F.-F.; Fan, X.-Y.; Jiang, F.-L.; Liu, Y. Fabrication of an acylhydrazone based fluorescence probe for $\mathrm{Al}^{3+}$. Sens. Actuators B Chem. 2017, 240, 916-925. [CrossRef]

58. Li, R.-Y.; Wei, Z.-L.; Wang, L.; Zhang, Y.; Ru, J.-X. A new salamo-based fluorescence probe to visually detect aluminum(III) ion and bio-imaging in zebrafish. Microchem. J. 2021, 162, 105720. [CrossRef]

59. Wang, Z.; Zhang, Y.; Yin, J.; Yang, Y.; Luo, H.; Song, J.; Xu, X.; Wang, S. A novel camphor-based “turn-on" fluorescent probe with high specificity and sensitivity for sensing mercury(II) in aqueous medium and its bioimaging application. ACS Sustain. Chem. Eng. 2020, 8, 12348-12359. [CrossRef]

60. Song, Y.; Tao, J.; Wang, Y.; Cai, Z.; Fang, X.; Wang, S.; Xu, H. A novel dual-responsive fluorescent probe for the detection of copper(II) and nickel(II) based on BODIPY derivatives. Inorg. Chim. Acta 2021, 516, 120099. [CrossRef] 
61. Wang, Y.; Zhu, Z.; Fan, C.; Liu, G.; Pu, S. A naphthalene-dansylhydrazine based ratiometric fluorescence probe for selectively detecting $\mathrm{Cu}^{2+}$. Tetrahedron Lett. 2020, 61, 151427. [CrossRef]

62. Zhao, Y.; Xu, L.; Kong, F.; Yu, L. Design and preparation of poly(tannic acid) nanoparticles with intrinsic fluorescence: A sensitive detector of picric acid. Chem. Eng. J. 2021, 416, 129090. [CrossRef]

63. Musib, D.; Devi, L.R.; Raza, M.K.; Chanu, S.B.; Roy, M. A New Thiophene-based Aggregation-induced Emission Chemosensor for Selective Detection of $\mathrm{Zn}^{2+}$ Ions and Its Turn Off. Chem. Lett. 2020, 49, 473-476. [CrossRef]

64. Liu, T.-T.; Xu, J.; Liu, C.-G.; Zeng, S.; Xing, Z.-Y.; Sun, X.-J.; Li, J.-L. A novel dual-function probe for recognition and differentiation of $\mathrm{Zn}^{2+}$ and $\mathrm{Al}^{3+}$ and its application. J. Mol. Liq. 2020, 300, 112250. [CrossRef]

65. Wang, Z.; Toffoletti, A.; Hou, Y.; Zhao, J.; Barbon, A.; Dick, B. Insight into the drastically different triplet lifetimes of BODIPY obtained by optical/magnetic spectroscopy and theoretical computations. Chem. Sci. 2021, 12, 2829-2840. [CrossRef] [PubMed]

66. Feng, L.; Deng, Y.; Wang, X.; Liu, M. Polymer fluorescent probe for $\mathrm{Hg}(\mathrm{II})$ with thiophene, benzothiazole and quinoline groups. Sens. Actuators B Chem. 2017, 245, 441-447. [CrossRef]

67. Ghosh, K.; Saha, I. Selective sensing of Zn(II) ion by a simple anthracene-based tripodal chemo- sensor. Tetrahedron Lett. 2010, 51, 4995-4999. [CrossRef]

68. Cui, X.; Si, Z.; Li, Y.; Duan, Q. Synthesis of telechelic PNIPAM ended with 9,10-dihydroacridine group as a recyclable and specific $\mathrm{Fe}^{3+}$ detection fluorescent sensor. Dye. Pigment. 2020, 173, 107873. [CrossRef]

69. Tang, X.; Liu, W.; Wu, J.; Lee, C.-S.; You, J.; Wang, P. Synthesis, Crystal Structures, and Photophysical Properties of TriphenylamineBased Multicyano Derivatives. J. Org. Chem. 2010, 75, 7273-7278. [CrossRef]

70. Ravichandiran, P.; Prabakaran, D.S.; Maroli, N.; Kim, A.R.; Park, B.-H.; Han, M.-K.; Ramesh, T.; Ponpandian, S.; Yoo, D.J. Mitochondria-targeted acridine-based dual-channel fluorescence chemosensor for detection of $\mathrm{Sn}^{4+}$ and $\mathrm{Cr}_{2} \mathrm{O}_{7}{ }^{2-}$ ions in water and its application in discriminative detection of cancer cells. J. Hazard. Mater. 2021, 419, 126409. [CrossRef]

71. Mu, X.; Shi, L.; Yan, L.; Tang, N. A 2-Hydroxy-1-naphthaldehyde Schiff Base for Turn-on Fluorescence Detection of $\mathrm{Zn}^{2+}$ Based on PET Mechanism. J. Fluoresc. 2021, 31, 971-979. [CrossRef] [PubMed]

72. Wang, P.; Sun, L.Y.; Wu, J.; Yang, X.; Lin, P.; Wang, M. A dual-functional colorimetric and fluorescent peptide-based probe for sequential detection of $\mathrm{Cu}^{2+}$ and $\mathrm{S}^{2-}$ in $100 \%$ aqueous buffered solutions and living cells. J. Hazard. Mater. 2021, 407, 124388. [CrossRef] [PubMed]

73. Wang, Y.; Zhou, J.; Zhao, L.; Xu, B. A dual-responsive and highly sensitive fluorescent probe for $\mathrm{Cu}^{2+}$ and $\mathrm{pH}$ based on a dansyl derivative. Dye. Pigment. 2020, 180, 108513. [CrossRef]

74. Wu, Y.C.; Shi, C.Q.; Chen, Z.G.; Zhou, Y.B.; Liu, S.M.; Zhao, J.Q. A novel hydroxyl-containing polyimide as a colorimetric and ratiometric chemosensor for the reversible detection of fluoride ions. Polym. Chem. 2019, 10, 1399-1406. [CrossRef]

75. Wu, Y.; Liu, S.; Chen, Z.; Zhao, J. Synthesis and properties of cardo-type polyimides containing hydroxyl groups for application in specific detection of fluoride ion. Dye. Pigment. 2020, 173, 107924. [CrossRef]

76. Magri, D.C.; Brown, G.J.; McClean, G.D.; De Silva, A.P. Communicating Chemical Congregation: A Molecular AND Logic Gate with Three Chemical Inputs as a "Lab-on-a-Molecule" Prototype. J. Am. Chem. Soc. 2006, 128, 4950-4951. [CrossRef]

77. Wu, Y.-C.; Luo, S.-H.; Cao, L.; Jiang, K.; Wang, L.-Y.; Xie, J.-C.; Wang, Z.-Y. Self-assembled structures of N-alkylated bisbenzimidazolyl naphthalene in aqueous media for highly sensitive detection of picric acid. Anal. Chim. Acta 2017, 976, 74-83. [CrossRef]

78. Jiang, K.; Luo, S.-H.; Pang, C.-M.; Wang, B.-W.; Wu, H.-Q.; Wang, Z.-Y. A functionalized fluorochrome based on quinolinebenzimidazole conjugate: From facile design to highly sensitive and selective sensing for picric acid. Dyes Pigment. 2019, 162, 367-376. [CrossRef]

79. Kumar, A.; Chae, P.S. Aggregation induced emission enhancement behavior of conformationally rigid pyreneamide-based probe for ultra-trace detection of picric acid (PA). Dye. Pigment. 2018, 156, 307-317. [CrossRef] 